\title{
Mocarstwa centralne a Bałkany. Studium działań dyplomatycznych Niemiec i Austro-Węgier w Europie Południowo-Wschodniej (1909-1913)
}

Zarys treści: Półwysep Bałkański ze względu na swoje geograficzne położenie na styku „świata zachodniego” i „świata Orientu” od wieków odgrywał ważną rolę zarówno w europejskiej polityce, jak i ekonomii. Jego znaczenie znacznie wzrosło w połowie XIX w., kiedy europejskie mocarstwa wkroczyły w tzw. erę imperialną. Trudno zatem dziwić się, że w tym właśnie czasie ten niewielki region, leżący na „krańcach cywilizowanej Europy”, stał się polem zaciętej walki o strefy wpływów. W rywalizacji tej wzięły udział także Niemcy i Austro-Węgry. Jakkolwiek państwa te odmiennie postrzegały ostateczne cele, zarówno w Berlinie, jak i w Wiedniu zdawano sobie sprawę, że uzyskanie przewagi nad konkurentami może mieć istotny wpływ nie tylko na rozwój rodzimego przemysłu, który zyskiwałby nowe rynki zbytu dla swojej produkcji, ale także na kształtowanie ogólnoeuropejskiej polityki. Tymczasem zachodzące na Bałkanach na początku XX w. procesy i głębokie zmiany, błędnie oceniane i bagatelizowane przez dyplomację mocarstw centralnych, przesądziły o dotkliwej porażce, którą poniosły one w walce o ugruntowanie swej pozycji w Europie Południowo-Wschodniej.

Outline of content: Due to its geographical location nestled between the "Western World" and the "World of the Orient", the Balkan Peninsula has for centuries been playing an important part both in European politics, and economy. Its significance increased sharply in the mid-nineteenth century, after the European powers entered the so-called imperial era. It is therefore not surprising that at that time this relatively small region at "the end of the civilised world" became the battlefield for zones of influence. The rivalry was also joined by Germany and Austro-Hungary. And although these states had different ultimate ends, it was known both in Berlin, and in Vienna that the advantage over the competitors and opponents could have a great impact not only on the development of national industry, which would gain a new ready market, but also on the shape of European policy. However, the processes of deep changes and transformations that occurred in the Balkans in the early twentieth century, wrongly identified and underestimated by the Central Powers, determined their abject failure in the attempts to strengthen their position in South-Eastern Europe. 
Słowa kluczowe: Niemcy, Austro-Węgry, mocarstwa centralne, Bałkany, Europa Południowo-Wschodnia, wojny bałkańskie 1912-1913

Keywords: Germany, Austro-Hungary, Central Powers, the Balkans, South-Eastern Europe, Balkan wars of 1912-1913

Geopolityczne położenie Półwyspu Bałkańskiego było od zawsze przyczyną dużego zainteresowania państw odgrywających kluczową rolę w Europie. Położenie to - pomiędzy światem Zachodu a światem Orientu - tworzyło z tej części naszego kontynentu niezwykle ważny region, o dużym znaczeniu ekonomicznym i strategicznym. Już w czasach antyku wiodły przez niego szlaki handlowe, łączące Europę Środkową i Północną, a w pewnym sensie także Zachodnią z Bliskim Wschodem i Azją Centralną, zaś w okresie średniowiecza stał się on polem starcia między chrześcijaństwem a islamem. W miarę upływu czasu rola Półwyspu jeszcze wzrosła. Od początku XIX w. o dominację w tym rejonie rywalizowały mocarstwa europejskie, które, korzystając $\mathrm{z}$ wewnętrznego kryzysu Turcji, dążyły do realizacji swych planów ekonomicznych i politycznych.

Spośród państw określonych później mianem mocarstw centralnych, do rywalizacji o strefy wpływów w tej części świata jako pierwsza przestąpiła Austria. Tak stan rzeczy podyktowany był przede wszystkim faktem, że posiadłości tego państwa leżały częściowo na Bałkanach, a kwestia zabezpieczenia centrum kraju przed potencjalnym zagrożeniem ze strony Turcji wymagała stałego przesuwania granic w kierunku południowym. Jednocześnie już w pierwszej połowie XIX w., w związku z upadkiem znaczenia Wysokiej Porty w Europie, coraz większą rolę zaczęły odgrywać względy ekonomiczne. Jakkolwiek monarchia habsburska nie należała do potęg gospodarczych Starego Kontynentu, rozwijający się przemysł austriacki potrzebował rynków zbytu dla swoich towarów i bezpiecznych dróg handlowych dla ich eksportu. W związku z tym, w tym okresie stworzona została koncepcja wskazująca Saloniki jako naturalny port dla austriackiego handlu zagranicznego, poprzez który możliwy stałby się wywóz towarów do państw położonych w basenie Morza Śródziemnego i dalej na Bliski Wschód i do Azji Centralnej.

Realizacja założeń tej koncepcji w drugiej połowie XIX w. przebiegała wielotorowo. Początkowo szczególną uwagę przywiązywano do działań, które prowadzić miały do stałego przesuwania granic w kierunku południowym, a ich ukoronowaniem były klauzule traktatu berlińskiego z 1878 r., przyznające Austro-Węgrom prawo okupacji Bośni i Hercegowiny oraz kontroli nad sandżakiem nowopazarskim. Idea ta w miarę upływu czasu spotykała się jednak z coraz większą krytyką ${ }^{1}$. Począwszy od połowy XIX stulecia monarchia habsburska pogrążyła się bowiem $\mathrm{w}$ poważnym kryzysie wewnętrznym i podczas gdy pod względem

\footnotetext{
1 T. von Sosnosky, Die Balkanpolitik Österreich-Ungarns seit 1866, Stuttgart/Berlin 1914, s. 173-174,
} 177. 
geopolitycznym państwo przedstawiało się jako mocarstwo, co podkreślała jeszcze samowystarczalność ekonomiczna, to pod względem narodowościowym ulegało stopniowemu rozpadowi ${ }^{2}$. Przyczyną takiego stanu rzeczy było przede wszystkim upowszechnianie się romantycznych idei wolnościowych, czego efektem stało się powstawanie w całej Europie ruchów narodowych, szczególnie aktywnych wśród tzw. narodów bezpaństwowych, w tym także tych, które zamieszkiwały w granicach monarchii habsburskiej. To z kolei stanowiło poważny problem, ponieważ Austro-Węgry - jak słusznie zauważył Otto Bickel - były państwem bez duszy narodowej ${ }^{3}$. Wprawdzie „niemieckość" była elementem wiodącym pod względem kulturalnym, jednak reprezentowała ją zaledwie $1 / 4$ obywateli, co w związku ze stale rosnącą w ciągu XIX w. samoświadomością narodową innych grup etnicznych nie mogło silnie związać z Austrią pozostałych części monarchii. Stąd też do takiej struktury wewnętrznej państwa musiała się także dopasować polityka zagraniczna i o ile jeszcze w ostatniej ćwierci XIX stulecia bardzo silnie akcentowano dążenie do pozyskania nowych nabytków terytorialnych i zapewnienia sobie dominującej pozycji w Europie, o tyle na początku XX w. politycy austro-węgierscy uświadomili sobie fakt, że każdy wstrząs, zarówno w pozytywnym, jak i negatywnym znaczeniu, może prowadzić do nieprzewidywalnych problemów wewnętrznych ${ }^{4}$.

W kontekście polityki bałkańskiej coraz dalej odchodzono więc od niezwykle wcześniej popularnej koncepcji dążenia do Salonik ${ }^{5}$ na rzecz lansowania tezy o nienaruszalności status quo na Bałkanach i zwrócenia uwagi na sprawy wewnętrzne. Warto jednak zaznaczyć, że rezygnacja $\mathrm{z}$ aktywnych działań na rzecz poszerzenia granic państwa na południu podyktowana była także innymi czynnikami, wśród których szczególne znaczenie miało rosnące zaangażowanie innych mocarstw europejskich w procesy zachodzące na Bałkanach. Od początku XIX w. swoją aktywność w tym rejonie wykazywała Rosja, której naczelnym celem stało się opanowanie lub zdobycie kontroli nad cieśninami czarnomorskimi, co miało zagwarantować swobodę żeglugi rosyjskiej floty handlowej i wojennej z Morza Czarnego na Morze Śródziemne. Jakkolwiek podejmowane przez Rosjan działania na rzecz przekształcenia mapy Półwyspu Bałkańskiego stały w sprzeczności z ówczesnymi planami monarchii habsburskiej, w Wiedniu zdawano sobie sprawę z faktu, że próby aktywnego przeciwdziałania doprowadzić mogą do konfliktu zbrojnego o bliżej nieokreślonych skutkach. Tym samym starano się unikać

${ }^{2}$ H. Bogdan, From Warsaw to Sofia. A History of Eastern Europe, Santa Fe 1989, s. 121-126; H.W. Steed, The Hapsburg Monarchy, London 1919, s. 225.

3 O. Bickel, Russland und die Entstehung des Balkanbundes 1912. Ein Beitrag zur Vorgrschichte des Weltkrieges. Dargestellt vorwiegend auf Grund des amtlichen Aktenmaterials, Königsberg/ Berlin 1933, s. 13.

${ }^{4} \mathrm{Na}$ temat lansowanej przez Agenora Gołuchowskiego tezy quieta non movere: H.W. Steed, op. cit., s. 226.

${ }^{5}$ Die große Politik der europäischen Kabinette, 1871-1914. Sammlung der diplomatischen Akten des Auswärtigen Amtes, hrsg. J. Lepsius, A. Mendelssohn-Bartholdy, F. Thimme, Berlin 1922-1926 (dalej: DGP), t. 26, nr 8927. 
zadrażnień i skupiono uwagę na budowaniu stref wpływów, które zagwarantować miały osiągnięcie założonych celów. Działania te podyktowane były także poczynaniami innych mocarstw, a zwłaszcza Wielkiej Brytanii i Francji, które, kierując się swoimi własnymi interesami, już w połowie XIX w. przyjęły na siebie rolę protektorów Turcji i wręcz wrogo odnosiły się do jakichkolwiek idei uszczuplania jej stanu posiadania.

Warto jednak podkreślić, że wyznaczanie stref wpływów nie było zadaniem łatwym. Poza stałą rywalizacją z Rosją, realizującą podobną politykę pod hasłem stawiania tamy pangermanizmowi, Austro-Węgry od drugiej połowy lat siedemdziesiątych XIX w. zmagać się musiały z penetracją Włoch, które w tym czasie podjęły próbę realizacji idei mare internum w odniesieniu do Adriatyku. Poza sporem, jaki wybuchł na linii Wiedeń - Rzym w kwestii przynależności Dalmacji, rywalizacja ta widoczna była także na ziemiach albańskich, gdzie oba państwa aktywnie wspierały konkurencyjne działania misjonarskie oraz tworzyły sieci szkół, nie szczędząc na ten cel znacznych środków finansowych ${ }^{6}$. Niemniej jednak w ramach działań podjętych bezpośredniego po zakończeniu obrad kongresu berlińskiego udało się monarchii habsburskiej roztoczyć kuratelę nad Serbią. Wynikiem tego było podpisanie w 1881 r. układu o współpracy oraz sojuszu obronnego. Dzięki temu Austro-Węgry nie tylko stały się głównym partnerem ekonomicznym Serbii, ale także uzyskiwały kontrolę nad jej polityką zagraniczną. Belgrad zobowiązywał się bowiem zarówno do zrzeczenia się pretensji do Bośni i Hercegowiny oraz sandżaku nowopazarskiego, jak i do zwalczania propagandy wielkoserbskiej w monarchii habsburskiej, współdziałania w kwestii tranzytu wojsk austro-węgierskich przez terytorium Serbii, a nawet udostępnienia swoich twierdz w przypadku prowadzonych przez Austrię w tej części Europy działań wojennych oraz do niezawierania jakichkolwiek umów międzynarodowych bez zgody Wiednia ${ }^{7}$. Dzięki sprawnie prowadzonej polityce w tym obszarze, ta austro-węgierska kuratela trwała niemal do $1908 \mathrm{r}^{8}{ }^{8}$ Swoją strefę wpływów monarchia habsburska starała się także poszerzyć, włączając do niej Bułgarię. Działania te, bardzo wyraźne już w czasie panowania Aleksandra Battenberga, przybrały jeszcze na sile w trakcie tzw. kryzysu bułgarskiego 1886-1887, kiedy Austro-Węgry zaangażowały się bardzo mocno w kwestię osadzenia na tronie w Sofii sprzyjającego im kandydata. Wykorzystując ówczesne antyrosyjskie nastawienie bułgarskich kręgów politycznych, Habsburgom udało

${ }^{6}$ O roli Albanii w planach Austro-Węgier świadczyć mogą m.in. słowa A. Gołuchowskiego, który w 1904 r. stwierdził: „wprawdzie Austro-Węgry same nie zamierzają zająć Albanii, ale nie dopuszczą, by to uczynił ktoś inny, a przede wszystkim Włochy", DGP, t. 20, nr 6401.

7 Z. Stefański, Wojna dyplomatów, „Świat Słowiański” 5, 1909, t. 1, nr 53, s. 332.

8 Warto jednak zaznaczyć, że w miarę upływu czasu Serbia starała się rozluźnić łączące ją z Wiedniem więzy. Już w czasie rządów Aleksandra Obrenovicia polityka serbska zaczęła wykazywać wyraźne trendy prorosyjskie. Kierunek ten został utrzymany także w trakcie panowania jego następcy - Piotra I, a podjęte przez Austro-Węgry próby nacisku ekonomicznego, m.in. przez sprowokowanie tzw. świńskiej wojny, nie przyniosły spodziewanych rezultatów w związku z pomocą, jakiej udzieliły Serbom Rosja i sąsiednia Bułgaria. 
się doprowadzić do wyboru Ferdynanda Coburga w 1887 r., ale silne wpływy Petersburga $\mathrm{w}$ społeczeństwie bułgarskim sprawiały, że możliwości ingerencji $\mathrm{w}$ wewnętrzne sprawy Bułgarii były bardzo ograniczone.

Zdecydowanie mniejszym zainteresowaniem Półwysep Bałkański cieszył się w Berlinie. Taki stan rzeczy wynikał przede wszystkim stąd, że ziemie niemieckie od czasów średniowiecza podzielone były na wiele niezależnych organizmów państwowych, a wiodące wśród nich Prusy koncentrowały się na wzmacnianiu swej pozycji w Europie Środkowej i podejmowaniu działań na rzecz skupiania wokół siebie innych państewek niemieckich. Istotne znaczenie miał również fakt, że Prusy nie miały bezpośredniej łączności z tą częścią kontynentu. Sytuacja uległa znacznej zmianie po zjednoczeniu Niemiec w $1871 \mathrm{r}$. Dynamicznie rozwijająca się niemiecka gospodarka, podobnie jak gospodarki innych mocarstw europejskich, zaczęła poszukiwać zarówno baz surowcowych, jak i rynków zbytu. Stąd też Niemcy aktywnie włączyły się w walkę o kolonialny podział Afryki i Azji Wschodniej, a równocześnie starały się rugować wpływy konkurentów z państw, które mogły stać się odbiorcą produkowanych przez nie towarów. Jednym z nich była Turcja, gdzie kapitał niemiecki skutecznie konkurował z francuskim, a zwłaszcza brytyjskim. Szczególne korzyści przynosił mu prowadzony z wielkim rozmachem handel bronią, a konsekwentna polityka w tym zakresie, wspierana przez najwyższe czynniki państwowe, bardzo szybko doprowadziła do wyparcia dostawców brytyjskich z tego segmentu rynku tureckiego. W 1883 r. firma Krupp uzyskała monopol na dostawy broni do Turcji, co przełożyło się na zacieśnienie współpracy niemiecko-tureckiej w dziedzinie wojskowości. W efekcie, planowaną już od dawna reorganizację armii tureckiej powierzono dwukrotnie w 1883 i 1908 r. niemieckiej misji wojskowej pod przewodnictwem gen. Colmara von der Goltz, a niemiecki sztab generalny w $1882 \mathrm{r}$. opracował plan przebudowy fortyfikacji Bosforu od strony Morza Czarnego. To potężne przyspieszenie ekspansji kapitału niemieckiego widoczne było także w innych dziedzinach. Odrzucając w 1895 r. angielskie propozycje podziału posiadłości Wysokiej Porty, Niemcy przystąpiły do prac mających uzdrowić także gospodarkę państwa tureckiego. Jeszcze w fazie przygotowań do tej akcji w 1889 r. uruchomiono tzw. lewantyńską linię okrętową, a banki niemieckie uzyskały koncesję na budowę linii kolejowej z Izmiru do Ankary, która, w dalekosiężnych planach założonego w tym celu Anatolijskiego Towarzystwa Kolejowego, stanowić miała fragment magistrali kolejowej łączącej Berlin z Bagdadem. Obie te inicjatywy miały przybliżyć II Rzeszę do bogatych w surowce terenów Azji Mniejszej i otworzyć niemieckiej gospodarce szerokie rynki zbytu na Bliskim Wschodzie i w Azji Środkowej9.

9 A. Czubiński, Miejsce Bałkanów w polityce wschodniej imperializmu niemieckiego (1871-1918), w: Państwa bałkańskie w polityce imperializmu niemieckiego w latach 1871-1945, w: Referaty $i$ komunikaty wygłoszone w czasie sympozjum zorganizowanego przez Zakład Historii Powszechnej, Nowożytnej i Najnowszej Instytutu Historii UAM w Poznaniu w dniach 24-25 listopada 1980 r., red. A. Czubiński, Poznań 1982, s. 25-40. 
Warto jednak podkreślić, że Niemcy, zwłaszcza w tzw. erze bismarckowskiej, starały się nie angażować politycznie $\mathrm{w}$ dynamiczne przemiany zachodzące w Europie Południowo-Wschodniej. Takie stanowisko podyktowane było przede wszystkim geopolitycznym położeniem Niemiec - pomiędzy Rosją a Francją, co zmuszało je do zwracania większej uwagi na zabezpieczenie własnych granic, niż angażowanie się $\mathrm{w}$ spory na drugorzędnej $\mathrm{z}$ ich punktu widzenia arenie bałkańskiej. Zupełna alienacja nie była jednak możliwa. Zbliżenie, jakie nastąpiło między Niemcami a Austro-Węgrami w trakcie obrad kongresu berlińskiego w 1878 r., potwierdzone następnie zawartym rok później układem sojuszniczym, tworzącym podwaliny pod nowy blok militarno-polityczny w Europie, mobilizowało Niemcy do analizowania sytuacji na Bałkanach. Dbając jednak przede wszystkim o własne interesy, aż do końca XIX w. prowadziły one często nielojalną wobec sojusznika politykę. Dobrym przykładem służyć tu mogą zawierane przez Niemcy porozumienia międzynarodowe. Latem 1887 r. za wiedzą, a być może nawet z inspiracji kanclerza Ottona von Bismarcka podpisane zostało między Austro-Węgrami, Wielką Brytanią i Włochami tzw. porozumienie śródziemnomorskie, którego celem miało być m.in. rugowanie wpływów rosyjskich z Półwyspu Bałkańskiego. Dokument ten niewątpliwie wzmacniał pozycję monarchii habsburskiej w tym rejonie, ale kilka miesięcy wcześniej Niemcy zawarły z Rosją tzw. traktat reasekuracyjny, o wyraźnie antyfrancuskim ostrzu, co sugerowało, że nie będą się one angażowały $\mathrm{w}$ jakiekolwiek próby destabilizacji sytuacji w Europie. Warto także zaznaczyć, że włączenie na wyraźne życzenie Bismarcka Włoch do dwuprzymierza w 1882 r., było z punktu widzenia Wiednia okolicznością niesprzyjającą. Jakkolwiek wyciszyło włoską propagandę rewindykacyjną w kwestii dalmatyńskiej, od tej pory monarchia habsburska zmuszona była brać pod uwagę działania Rzymu na terenie Bałkanów. Taki stan rzeczy trwał do początku XX w. Zbliżenie Rosji i Francji, potwierdzone traktatem sojuszniczym z $1894 \mathrm{r}$. oraz układy polityczne zawarte przez oba te państwa z Wielką Brytanią w 1907 i 1904 r., które stworzyły konkurencyjny dla Trójprzymierza blok militarno-polityczny, a także podejmowane przez Włochy działania na rzecz rozluźnienia więzów łączących je z Berlinem i Wiedniem, skłoniły władze niemieckie do jednoznacznego wsparcia działań Austro-Węgier na arenie międzynarodowej, w tym także tych, które bezpośrednio dotyczyły kwestii bałkańskich. Spektakularnym dowodem tej kooperacji była postawa Niemiec w trakcie kryzysu bośniackiego na przełomie 1908 i 1909 r., kiedy Berlin nie tylko stanął po stronie sojusznika, ale także niedwuznacznie zamanifestował swoje poparcie, czym zmusił Rosję do uznania aneksji Bośni i Hercegowiny.

Aneksja Bośni i Hercegowiny, wbrew intencjom Wiednia, stała się początkiem całego łańcucha zdarzeń prowadzących do wybuchu wojen bałkańskich, a kluczowym ogniwem stała się reakcja międzynarodowa na to wydarzenie. $\mathrm{W}$ powszechnym mniemaniu stanowiło ono poważne naruszenie ducha traktatu berlińskiego i jakkolwiek zmieniało istniejącą sytuację tylko formalnie, spotkało się z ogólnoeuropejską krytyką. Wprawdzie inne mocarstwa, poza Rosją, 
ograniczyły się jedynie do wyrażenia swego niezadowolenia i dyskusji na temat potencjalnych skutków, ale na Bałkanach krok Austro-Węgier uznany został, zwłaszcza w Serbii, za nieprzyjacielski, co omal nie doprowadziło do wybuchu konfliktu zbrojnego. Chociaż sytuację udało się opanować, chaos, jaki zapanował w dobie kryzysu bośniackiego, stwarzał możliwość przedsięwzięcia nowych inicjatyw politycznych. Naruszenie traktatu berlińskiego przez jednego z jego gwarantów uświadomiło państwom bałkańskim, że klauzule tego dokumentu nie są ostateczne. Stąd też niemal bezpośrednio po zakończeniu kryzysu rozpoczęły się próby stworzenia bloku militarno-politycznego, którego celem byłaby realizacja ich narodowych celów.

Nie było to jednak zadanie łatwe. Zadawnione pretensje oraz ciągnąca się od wielu dziesięcioleci rywalizacja o wpływy w Macedonii znacznie utrudniały osiągnięcie porozumienia, ale jednocześnie zdawano sobie sprawę, że być może jest to jedyna szansa na ostateczne rozwiązanie tzw. kwestii tureckiej i pozbawienie Wysokiej Porty jej europejskich posiadłości. Szanse wykorzystania ewentualnego zbliżenia między państwami bałkańskimi dostrzegały także wielkie mocarstwa. W ich opinii budowa bloku militarnego na Bałkanach mogła zmienić układ sił w Europie w coraz wyraźniej rysującym się konflikcie między mocarstwami centralnymi a ententą. Dlatego też, zdając sobie sprawę z różnic dzielących państwa bałkańskie, mocarstwa podjęły próbę zbliżenia ich do siebie. Szczególną aktywność na tym polu wykazywała dyplomacja rosyjska. W pierwszej kolejności Rosjanie podjęli wysiłki na rzecz wzmocnienia swych wpływów w Bułgarii, która w okresie bezpośrednio poprzedzającym aneksję Bośni i Hercegowiny silnie związała się z Austro-Węgrami ${ }^{10}$. Działania te polegały początkowo przede wszystkim na pośrednictwie w negocjacjach między Bułgarią a Turcją, które toczyły się na przełomie 1908 i 1909 r. w kwestii odszkodowania za utratę kontroli przez Wysoką Portę nad niedawnym lennikiem. Dzięki mediacji rosyjskiej rozmowy zakończyły się sukcesem, a pozycja Petersburga wyraźnie wzrosła. Kolejnym etapem była podjęta przez ambasadora rosyjskiego w Konstantynopolu, Nikołaja Czarykowa, próba stworzenia bloku państw bałkańskich na czele z Turcją ${ }^{11}$, który miał zabezpieczać interesy ententy w tej części Europy. Jakkolwiek działania te nie zakończyły się sukcesem, dały dobry punkt wyjścia do dalszych prac w tym obszarze.

${ }^{10}$ Efektem tej współpracy była zgoda Austro-Węgier na ogłoszenie przez Bułgarię niepodległości. Warto jednak zaznaczyć, że dyplomacja habsburska starała się wykorzystać ten fakt dla własnych celów, jako wydarzenie mające odwrócić uwagę Europy od aktu aneksji Bośni i Hercegowiny.

11 Österreich-Ungarns Aussenpolitik von bosnischen Krise 1908 bis zum Kriegsausbruch 1914. Diplomatische Aktenstücke des Österreich-Ungarischen Ministeriums des Äussem, ausgew. L. von Bittner, A.F. Pribram, H. Srbik, H. Übersberger, Wien-Leipzig 1930 (dalej: ÖUA), t. 2, nr 1823, 1839, 1890, t. 3, nr 2951; DGP, t. 27, nr 9744 
Wzrost aktywności rosyjskiej bardzo poważnie zaniepokoił gabinet wiedeński ${ }^{12}$, który za wszelką cenę starał się zatrzymać Bułgarię po swojej stronie i nie dopuścić do jej ewentualnego wejścia do antyaustriackiego bloku serbsko-tureckiego ${ }^{13}$. Podjęte przez austriackiego ministra spraw zagranicznych Aloisa Aehrenthala próby sondowania stanowiska bułgarskiego pozwoliły mu ustalić, że Bułgaria nie widzi żadnych korzyści w zbliżeniu z Serbią czy Turcją ${ }^{14}$. Wykorzystując te informacje, gabinet wiedeński, zgodnie $\mathrm{z}$ radami bułgarskiego ministra wojny gen. Danaiła Nikołaewa ${ }^{15}$, podjął próbę związania Bułgarii sojuszem. Jednak rozmowy na ten temat musiały być podjęte albo z ministrem spraw zagranicznych, albo z carem Ferdynandem. Tymczasem gen. Stefan Paprikow reprezentował stanowisko zdecydowanie antyaustriackie, a bułgarski monarcha wstrzymywał się z podjęciem ostatecznej decyzji i postanowił utrzymywać Austro-Węgry w niepewności. Tymczasem działania popieranej przez Wielką Brytanię Rosji wywołały poważne obawy w Niemczech ${ }^{16}$. Szczególne zaniepokojenie w Berlinie wywołała zwłaszcza wygłoszona przez rosyjskiego ministra spraw zagranicznych Aleksandra Izwolskiego 12 grudnia 1908 r. w Dumie mowa, w której postulował on zbliżenie państw bałkańskich z Turcją w celu stworzenia jednolitego bloku, mającego być tamą dla wpływów austro-węgierskich i niemieckich w Europie Południowo-Wschodniej. Stąd też kanclerz Bernhard von Bülow zaczął naciskać na Aehrenthala, aby ten zintensyfikował rozmowy z Bułgarią ${ }^{17}$. Austriacki minister zdawał sobie jednak

12 Warto jednak podkreślić, że początkowo zarówno w Wiedniu, jak i w Berlinie nie wierzono, aby wysiłki rosyjskie mogły zakończyć się powstaniem sojuszu państw bałkańskich, ÖUA, t. 1, $\mathrm{nr}$ 703. Kierując się takim przeświadczeniem i zadowalając się podpisaniem porozumienia $\mathrm{z}$ Turcją odnośnie do aneksji Bośni i Hercegowiny, Austro-Węgry odrzuciły wysuwane w tym czasie przez Turcję propozycje zawarcia układu sojuszniczego, ibidem, t. 1, nr 551, 737, 739, 762, 781, 818, 1035. Nastawienie to uległo zmianie dopiero latem 1909 r., kiedy działania Czarykowa w Konstantynopolu nabrały rozmachu, budząc poważne obawy w Berlinie. Stąd też konieczność zawarcia konwencji austriacko-tureckiej, która zabezpieczałaby interesy państw centralnych na Bałkanach i uniemożliwiłaby Rosji stworzenie sojuszu bałkańskiego pod własną egidą, podkreślał bardzo mocno cesarz niemiecki Wilhelm II, ibidem, t. 2, nr 1828; DGP, t. 27, nr 9888. Jednak na skutek negatywnego stanowiska Aehrenthala do podpisania porozumienia nie doszło, mimo że strona turecka w listopadzie 1909 r. wyraziła zainteresowanie zawarciem konwencji wojskowej, która połączyłaby Austro-Węgry, Rumunię i Turcję.

13 Rozmowy między Serbią i Turcją na ten temat rozpoczęły się już w październiku 1908 r.; British Documents on the Origins of the War 1898-1914, London 1926 (dalej: BD), t. 5, nr 440, 443, 445, 462; O. Bickel, op. cit., s. 24, przyp. 83. Mimo zaangażowania brytyjskiego nie zakończyły się one sukcesem, a głównym powodem takiego stanu rzeczy były naciski Turcji, aby ewentualny sojusz skierowany został także przeciw Bułgarii, BD, t. 5, nr 452, 455; O. Bickel, op. cit., s. 27.

14 ÖUA, t. 1, nr 746.

15 ÖUA, t. 2, nr 1305.

16 Bernhard von Bülow uważał, że plany te pokrzyżować może zdecydowana akcja podjęta przez Aehrenthala zarówno w Turcji, jak i w pozostałych państwach bałkańskich: Rumunii, Grecji i Bułgarii, DGP, t. 26, nr 9295.

17 Rząd niemiecki stał bowiem na stanowisku, że przeciągnięcie Bułgarii na stronę państw centralnych sprawi, iż w przypadku ewentualnego konfliktu austriacko-serbskiego Rosja będzie musiała 
sprawę z faktu, że w związku z chwiejnym, a zarazem porywczym charakterem Ferdynanda, rozmowy muszą być prowadzone wolno i ostrożnie ${ }^{18}$. Ostatecznie 3 stycznia 1909 r., za pośrednictwem posła austro-węgierskiego w Sofii, Duglasa Thurna, przekazano Ferdynandowi ściśle tajną propozycję aliansu ${ }^{19}$ na wypadek ewentualnego konfliktu Austro-Węgier z Serbią, Bułgarii z Turcją lub jednoczesnego ataku turecko-serbskiego na monarchię habsburską i Bułgarię ${ }^{20}$. Jednocześnie Thurn ustnie poinformował bułgarskiego monarchę o pozytywnym stosunku władz austro-węgierskich do idei rozszerzenia po zakończeniu wojny granic bułgarskich o część ziem serbskich ${ }^{21}$. Propozycja ta spotkała się z zainteresowaniem cara Ferdynanda, ale zaproponował on, aby dalsze rozmowy skoncentrowały się przede wszystkim na mającej połączyć oba państwa konwencji wojskowej oraz aby rozmowy na ten temat prowadził premier Aleksandyr Malinow ${ }^{22}$. Tymczasem bułgarski gabinet jednoznacznie oświadczył, że Bułgaria daleka jest od wspierania Austro-Węgier przeciw Serbii ${ }^{23}$. W związku z tym rozmowy uległy zawieszeniu ${ }^{24}$, a następnie zostały przerwane ${ }^{25}$. Dzięki temu Rosja mogła zrealizować swój plan i mimo poważnych problemów doprowadzić wiosną 1912 r. do stworzenia sojuszu bułgarsko-serbskiego, który po przystąpieniu doń Grecji i Czarnogóry przekształcił się w blok bałkański.

Rozmowy prowadzone wiosną i latem 1912 r. przez państwa bałkańskie utrzymywane były w ścisłej tajemnicy. Jedynym wielkim mocarstwem orientującym w treści zawieranych porozumień była Rosja, której dyplomaci bezpośrednio

podzielić swe sympatie między stojące po różnych stronach frontu państwa słowiańskie, co może zdecydowanie osłabić jej działania, DGP, t. 26, nr 9292.

18 ÖUA, t. 1 , nr 828 i 856.

19 Było to potwierdzeniem wysuwanych przez Aehrenthala koncepcji, poprzez które wcześniej chciał doprowadzić do niesnasek między oboma państwami i udaremnić rosyjską akcję, mającą na celu ich zbliżenie, DGP, t. 26, nr 8927, 9294; B. von Siebert, Diplomatische Aktenstücke zur Geschichte der Ententepolitik der Vorkriegsjahre, Berlin 1921, t. 2, nr 618; ÖUA, t. 1, nr 835.

20 ÖUA, t. 1, nr 828 i 835.

${ }^{21}$ B. von Siebert, op. cit., s. 146-148, 522-525.

22 ÖUA, t. 1, nr 879.

${ }^{23}$ O. Bickel, op. cit., s. 53.

${ }^{24}$ Kryzys w pertraktacjach spowodował także negatywny stosunek Aehrenthala do rozmów na temat konwencji wojskowej (ÖUA, t. 1, nr 923, 927), aczkolwiek rozmowy na ten temat prowadzone były jeszcze z początkiem marca 1909 r., ibidem, t. 2, nr 1103.

25 ÖUA, t. 2, nr 960. Taki stan rzeczy podyktowany był przede wszystkim przyjęciem przez Bułgarię rosyjskiej propozycji pomocy finansowej, co doprowadziło do zerwania rozmów na temat sojuszu; ibidem, t. 1, nr 960; równocześnie rozpoczęto jednak rozmowy na temat wspólnego działania przeciw Serbii, co wywołało w Belgradzie duże zaniepokojenie, B. von Siebert, op. cit., t. 1, nr 82; ÖUA, t. 1, nr 995. Ferdynand, kontynuując wytyczony przez siebie kurs polityczny, który uchronić miał Bułgarię przed silniejszymi związkami czy to z Austro-Węgrami, czy to z Rosją, obu stronom składał daleko idące zapewnienia o swej lojalności. Podczas rozmów w Petersburgu w lutym 1909 r. potwierdzał chęć zerwania wszelkich kontaktów z Wiedniem, równocześnie jednak podczas swej nieoficjalnej wizyty w Wiedniu w czerwcu 1909 r. składał zupełnie przeciwne deklaracje, DGP, t. 26, nr 9347, t. 27, nr 9768. 
uczestniczyli w prowadzonych rozmowach, ale nie informowała o nich nawet sojuszników z ententy, ograniczając się jedynie do przekazywania im ogólnych informacji. Stąd też mocarstwa centralne nie miały możliwości reagowania ad hoc, ani nawet komentowania zachodzących na Bałkanach procesów. Warto jednak podkreślić, że zarówno w Wiedniu, jak i w Berlinie nie starano się reagować na szczątkowe informacje, które pojawiały się w Europie w pierwszej połowie 1912 r., z góry uznając, że stworzenie bloku państw bałkańskich nie jest możliwe. Opinia ta oparta była na przekonaniu, że konflikt interesów między potencjalnymi sojusznikami $^{26}$, a zwłaszcza rywalizacja o wpływy w Macedonii między Bułgarią i Serbią, przekreśla szanse na stworzenie podstaw bliższej współpracy. Jednocześnie zakładano, że jakikolwiek blok bałkański bez udziału Turcji, która mogłaby łagodzić napięcia na linii Belgrad - Sofia, jest niewartą uwagi utopią. Stąd też więcej uwagi poświęcano działaniom Czarykowa, ale kiedy zakończyły się one niepowodzeniem, wszelkie napływające informacje na temat tworzenia sojuszu bałkańskiego uznawano za nieistotne. Tą zadziwiającą beztroską wykazywały się nie tylko rządy państw centralnych, ale także ich dyplomaci na Bałkanach.

Pierwsze informacje na temat sojuszu bułgarsko-serbskiego trafily do mocarstw centralnych już w pierwszej połowie kwietnia $1912 \mathrm{r}$. W tym czasie niemiecki minister spraw zagranicznych Alfred von Kinderlen-Weachter wszedł w posiadanie fragmentu układu ${ }^{27}$, o czym niezobowiązująco powiadomił Rumunię $e^{28}$ i Austro-Węgry ${ }^{29}$, a w połowie 1912 r. rząd wiedeński uzyskał informację o zawarciu sojuszu bułgarsko-greckiego ${ }^{30}$. Te niezwykle cenne wiadomości bardzo szybko uznane zostały jednak za mało istotne. Zalecono wprawdzie posłowi niemieckiemu w Sofii, Rudolfowi Mittagowi, ich sprawdzenie, ale działania te nie dały żadnych rezultatów. W związku z tym za miarodajne uznano zapewnienia rządu bułgarskiego ${ }^{31}$, że doniesienia te są nieprawdziwe i nadal nie wierzono w istnienie układów łączących państwa bałkańskie, zakładając co najwyżej zawarcie bliżej nieokreślonych umów ustnych $^{32}$. Znaczny wpływ na taką postawę miały również kurtuazyjne wizyty, jakie

26 ÖUA, t. 4, nr 3703.

27 Informację tę uzyskał zapewne od posła serbskiego w Berlinie Milana Bogićevića, który już pod koniec marca 1912 r. był dokładnie poinformowany o treści porozumienia bułgarsko-serbskiego. Bogićević nie aprobował ani kierunku polityki serbskiej, ani mieszania się do niej dyplomacji rosyjskiej, o czym oficjalnie informował polityków niemieckich; O. Bickel, op. cit., s. 136, przyp. 594. Na ten temat także: W. Schröder, England, Europa und der Orient, Stuttgart 1938, s. 80.

28 W. Schröder, op. cit., s. 84.

29 ÖUA, t. 4, nr 3530, 3540. W tym samym czasie pierwsze informacje o sojuszu bułgarsko-serbskim dotarły do Konstantynopola, ÖUA, t. 4, nr 3571.

30 ÖUA, t. 4, nr 3549.

31 ÖUA, t. 4, nr 3601, 3607, 3703, 3728, 3730, 3746, 3747; DGP, t. 33, nr 12114. Zapewnienia takie składała także strona serbska, DGP, t. 33, nr 12107; ÖUA, t. 4, nr 3689.

32 ÖUA, t. 4, nr 3571, 3601, 3607. Równocześnie nie brano pod uwagę napływających informacji, które świadczyły, że państwa bałkańskie przygotowują się do konfrontacji z Turcją, DGP, t. 33, nr 12072. 
car Ferdynand składał zarówno w Wiedniu, jak i w Berlinie, które sugerowały, iż mimo zacieśnienia po 1909 r. kontaktów z Rosją Bułgaria zachowała jednak prozachodni kurs w swej polityce zagranicznej i nie będzie występować przeciw Turcji, otoczonej opieką niemiecko-austriacką.

Jakkolwiek ani w monarchii habsburskiej, ani w Niemczech nie przewidywano, aby europejskim posiadłościom Wysokiej Porty groziło niebezpieczeństwo ze strony uważanego za nierealny bloku bałkańskiego, dostrzegano jednak możliwość wybuchu niepokojów na Półwyspie Bałkańskim w związku z ewentualną ingerencją państw bałkańskich w kwestię albańską. Zagrożenie takie szczególnie wyraźnie dostrzegano w Wiedniu. Politycy austro-węgierscy, którzy z rosnącym niepokojem obserwowali wzbierające na sile powstanie w Albanii, obejmujące swym zasięgiem tereny, do których już od dawna pretensje zgłaszały zarówno Serbia, jak i Bułgaria, obawiali się, że państwa bałkańskie będą chciały włączyć się w wydarzenia w celu zabezpieczenia swych stref wpływów ${ }^{33}$. Takiej ewentualności postanowiono sprzeciwić się z całą stanowczością. Równocześnie jednak zdawano sobie w Wiedniu sprawę, że aktywne zaangażowanie się $\mathrm{w}$ wydarzenia na Bałkanach spowodować może nie tylko konflikt z państwami bałkańskimi, ale przede wszystkim $z$ innymi mocarstwami, które wprawdzie zaakceptowały aneksję Bośni i Hercegowiny, ale na dalsze wzmocnienie wpływów monarchii habsburskiej w Europie Południowo-Wschodniej zgody wyrażać nie zamierzają. Tymczasem na konflikt zbrojny, który w efekcie mógł przynieść ogólnoeuropejską wojnę, Austro-Węgry nie były gotowe ${ }^{34}$.

Fakt ten skłonił austriackiego ministra spraw zagranicznych, Leopolda Berchtolda, do szukania sprzymierzeńców, którzy wsparliby jego wysiłki na rzecz zachowania terytorialnego status quo na Bałkanach ${ }^{35}$. Aby akcja ta mogła przynieść spodziewane rezultaty, niezbędne jednak było pozyskanie nie tylko sojuszników $\mathrm{z}$ trójprzymierza, ale także przekonanie ententy o konieczności podjęcia tego typu działań. Dlatego też, po zapewnieniu sobie poparcia Niemiec w połowie lipca ${ }^{36}$, 13 sierpnia 1912 r. gabinet wiedeński zwrócił się do rządów mocarstw europejskich z memorandum w sprawie wspólnej akcji na Bałkanach ${ }^{37}$. Pragnąc odsunąć wszelkie podejrzenia o bezpośrednią ingerencję w wydarzenia na Półwyspie, Berchtold zaproponował, aby mocarstwa, korzystając ze zmiany rządu w Turcji ${ }^{38}$,

33 B. von Siebert, op. cit., s. 532-533, 535-537.

34 DGP, t. 33, nr 12073.

35 B. von Siebert, op. cit., s. 533-534.

36 Ibidem, s. 523-533. Równocześnie podkreślić jednak należy, że Kinderlen mocno rozczarowany był faktem, iż gabinet wiedeński prowadzi niezależną od sojusznika politykę w odniesieniu do ważnego z punktu widzenia niemieckiej racji stanu terenu, ÖUA, t. 4, nr 3714, 3718; DGP, t. 33 , nr 12124 .

37 ÖUA, t. 4, nr 3687, 3712, 3714; М. Семов, Победителят проси мир. Балканските войни 1912-13, София 1995, s. 78; В. von Siebert, op. cit., s. 533-534.

38 DGP, t. 33, nr 12068. 
wywarły wspólnie nacisk na nowy gabinet w Konstantynopolu na rzecz rzeczywistego wprowadzenia zapowiadanych reform w Albanii i Macedonii. Krok taki miał $\mathrm{z}$ jednej strony wytworzyć $\mathrm{w}$ stolicach bałkańskich przeświadczenie, że od tej pory Wysoka Porta dbać będzie o interesy innych narodów zamieszkujących jej terytorium, a $\mathrm{z}$ drugiej zapewnić spokój na Półwyspie Bałkańskim poprzez odebranie państwom bałkańskim podstaw do interwencji ${ }^{39}$. Wszelkie kwestie z tym związane przedstawiciele mocarstw omówić mieli podczas zwołanej $\mathrm{w}$ tym celu konferencji ${ }^{40}$. Plan ten spotkał się $\mathrm{z}$ życzliwym przyjęciem w Wielkiej Brytanii ${ }^{41}$ oraz Francji, która przewidywała nawet udzielenie Rosji i Austro-Węgrom specjalnego mandatu, dającego im możliwość wspólnego działania na rzecz ograniczenia niepokojów na Bałkanach oraz zachowania status $q u o^{42}$. Stanowisko to poparte zostało ostatecznie także przez Rosję ${ }^{43}$, która, mimo pełnej wiedzy na temat wojennych planów państw bałkańskich, starała się do końca zachować pozory, że Petersburg, na równi z innymi mocarstwami, dążyć będzie do zachowania pokoju na Bałkanach. Mimo tej pozornej zgodności wkrótce okazało się jednak, że każde $\mathrm{z}$ wielkich mocarstw inaczej wyobrażało sobie zakres działań. W związku z tym pertraktacje na temat wspólnej akcji znacznie się przeciągały ${ }^{44}$, a ostatecznie projekt został odrzucony ${ }^{45}$. Nie oznaczało to jednak całkowitego porzucenia przez mocarstwa prób zażegnania konfliktu na Bałkanach.

Ster akcji dyplomatycznej objął teraz premier Francji, Raymond Poincaréét, a gorącym orędownikiem akcji francuskiej stał się natychmiast rosyjski minister spraw zagranicznych Sergiusz Sazonow ${ }^{47}$. Zaskoczony rozwojem sytuacji na Bałkanach rząd rosyjski, zdając sobie sprawę z faktu, że w ewentualny konflikt nie zaangażują się ani Francja, ani Wielka Brytania, a jakiekolwiek próby samodzielnego nacisku na sojuszników bałkańskich mogą poważnie nadszarpnąć zdobyte z tak wielkim trudem wpływy w tej części Europy, podjął kroki na rzecz pokojowego

39 B. von Siebert, op. cit., s. 533-534; R. Poincaré, Geneza wojny światowej. Sześć odczytów wygłoszonych w Paryżu w roku 1921, Kraków 1921, s. 71.

40 B. von Siebert, op. cit., s. 537.

${ }^{41}$ Ibidem, s. 538, 553. Równocześnie jednak rząd brytyjski z powątpiewaniem wyrażał się o możliwościach wprowadzenia go w życie, BD, t. 9, nr 715.

42 B. von Siebert, op. cit., s. 535, 551-552.

43 DGP, t. 33, nr 12104.

${ }^{44}$ Znaczny wpływ miało tu także stanowisko Turcji, która była zrażona do mocarstw w związku z brakiem ich interwencji w sprawie konfliktu z Włochami, G. Roloff, Die Entstehung des Balkanbundes von 1912, Geissen 1922, s. 18; teraz zdecydowanie odmawiała poddania się ich dyktatowi, B. von Siebert, op. cit., s. 546-550.

45 B. von Siebert, op. cit., s. 546-550; Der diplomatische Schriftwechsel Iswolskis 1911-1914, hrsg. F. Stieve, Berlin 1926, t. 2, nr 508. Znaczny wpływ na ten fakt miały negatywne opinie wyrażane na temat planu przez państwa bałkańskie (BD, t. 9, nr 658, 659) oraz Turcję (DGP, t. 33, nr 12091, 12093, 12119; ÖUA, t. 4, nr 3731, 3766).

46 B. von Siebert, op. cit., s. 537, Der diplomatische Schriftwechsel..., t. 2, nr 439.

47 R. Poincaré, op. cit., s. 72. 
rozwiązania sytuacji na Bałkanach ${ }^{48}$. Szczególne zaniepokojenie Petersburga budziło utrzymujące się napięcie $\mathrm{w}$ stosunkach turecko-czarnogórskich ${ }^{49}$ oraz wzrost nastrojów prowojennych w Bułgarii ${ }^{50}$. W dniu 29 sierpnia 1912 r., w skierowanym do Poincaré telegramie, francuski ambasador w Petersburgu Georges Louis doniósł, że w trakcie prywatnej rozmowy Sazonow zasugerował wspólną interwencję $\mathrm{w}$ stolicach państw bałkańskich i Konstantynopolu oraz pozytywnie ustosunkował się do współpracy z innymi mocarstwami ${ }^{51}$. Plan ten zyskał aprobatę Francji ${ }^{52}$, która równolegle $\mathrm{z}$ naciskiem dyplomatycznym podjęła działania na rzecz zmuszenia do poddania się woli mocarstw najniebezpieczniejszej, w jej ocenie, dla status quo na Bałkanach Bułgarii, poprzez odmowę udzielenia kredytów na ewentualny zakup potrzebnych materiałów wojennych i uzbrojenia.

W tym czasie Sazonow rozpoczął podróż po stolicach europejskich, podczas której starał się pozyskać rządy innych mocarstw do wspólnego działania. Przedsięwzięta przez rząd rosyjski akcja nie przyniosła jednak spodziewanych efektów. Jakkolwiek zarówno w Londynie, jak i w Berlinie plany rosyjsko-francuskie przyjmowano z dużym zainteresowaniem ${ }^{53}$, ani Niemcy, ani Wielka Brytania nie zadeklarowały otwarcie chęci aktywnego włączenia się w próby zażegnania konfliktu na Bałkanach ${ }^{54}$. W związku z tym dyplomacja rosyjska podjęła decyzję o samodzielnym działaniu. W dniu 17 września $1912 \mathrm{r} .{ }^{55}$ podczas spotkania $\mathrm{z}$ ambasadorem Turcji w Berlinie Sazonow przedłożył projekt daleko idących

${ }^{48}$ M. Tanty, Rosja wobec wojen bałkańskich 1912-1913, Warszawa 1970, s. 68-74. Szczególna aktywność Rosji spowodowana była obawami, że wojna na Bałkanach może przerodzić się w konflikt o zasięgu ogólnoeuropejskim, do którego Rosja nie była przygotowana, Материаль по истории франко-русских отночений за 1910-1914 г2. Сборник секретных дипломатических документов Бывш. Императорского Министерства Иностранных Дел, отв. ред. Р. Маршан, Москва 1922, s. 289 i n.; Der diplomatische Schriftwechsel..., t. 1, nr 117. Równocześnie rząd rosyjski liczył na szybkie zakończenie wojny włosko-tureckiej, co znacząco mogło ostudzić wojenne nastroje w państwach bałkańskich, Der diplomatische Schriftwechsel..., nr 365.

49 Der diplomatische Schriftwechsel..., t. 2, nr 466.

${ }^{50}$ B. von Siebert, op. cit., s. 538.

51 R. Poincaré, op. cit., s. 72.

52 Ibidem.

5317 września 1912 r. ambasador francuski w Berlinie Paul Cambon donosił premierowi Poincaré: „pan Sazonow wyjawił rządowi niemieckiemu obawy z powodu zachowania się Bułgarii i Serbii i zauważył, że dla mocarstw nadszedł czas porozumienia się co do środków zlokalizowania wojny na wypadek gdyby ta miała wybuchnąć. Pan von Kinderlen [...] oświadczył na to, że jest w zupełności skłonnym do przyłączenia się do tych poglądów", R. Poincaré, op. cit. s. 73. Plan rosyjsko-francuski cieszył się także zainteresowaniem Wielkiej Brytanii, B. von Siebert, op. cit., s. 538.

${ }^{54}$ Niechętne stanowisko Niemiec podyktowane było z jednej strony obawą przed stratą zainwestowanych w Turcji kapitałów, a z drugiej niechęcią do popierania Rosji przeciw prowadzącym aktywną politykę bałkańską Austro-Węgrom, B. von Siebert, op. cit., s. 546-550; Der diplomatische Schriftwechsel..., t. 2, nr 508; ÖUA, t. 4, nr 3718; tym bardziej że oba państwa ustaliły kierunki swej polityki bliskowschodniej podczas dwudniowego spotkania kanclerza Niemiec Theobalda Bethmanna-Hollwega $\mathrm{z}$ austriackim ministrem spraw zagranicznych L. Berchtoldem w Buchlau na początku września 1912 r., B. von Siebert, op. cit., s. 536.

55 R. Poincaré, op. cit., s. 73. 
reform w Macedonii i stanowczo nalegał, aby gabinet w Konstantynopolu jak najszybciej wdrożył go w życie ${ }^{56}$. Plan ten przewidywał wprowadzenie zmian, dzięki którym ludność chrześcijańska w europejskich posiadłościach Wysokiej Porty uzyskać miała przede wszystkim zapewnienie bezpieczeństwa osób i mienia, równość wobec prawa oraz udział w administracji lokalnej, odpowiadający etnicznemu składowi tejże ludności w poszczególnych częściach państwa tureckiego ${ }^{57}$. Nie do końca odpowiadało to jednak planom francuskim. Stąd też odpowiedź na przekazaną przez ambasadora rosyjskiego w Paryżu Aleksandra Izwolskiego informację o podjętej przez Sazonowa inicjatywie była jednoznaczna - Francja poprze rosyjską ideę tylko wówczas, jeżeli ta uzyska aprobatę nie tylko usiłującej trzymać się z dala od konfliktu na Bałkanach Wielkiej Brytanii, ale także Niemiec i Austro-Węgier ${ }^{58}$. Przy takim nastawieniu sojusznika trudno było się spodziewać, aby plan rosyjski zyskał aprobatę innych mocarstw.

Równocześnie Poincaré prowadził ożywioną korespondencję z rządem niemieckim ${ }^{59}$. W toku dyskusji niemiecki minister spraw zagranicznych Alfred von Kinderlen, przewidując, że wybuch wojny na Bałkanach jest nieunikniony, opowiedział się za ograniczeniem terytorialnym konfliktu poprzez wspólne oświadczenie mocarstw skierowane do państw bałkańskich. Deklaracja ta miała wyraźnie stwierdzać, że nie dopuszczą one do jakichkolwiek zmian terytorialnych na Bałkanach. Jednocześnie zaproponował on, aby w imieniu mocarstw akcję prowadziły Rosja i Austro-Węgry ${ }^{60}$. Plan ten uzyskał pełne poparcie Francji ${ }^{61}$, a o wspólnych francusko-niemieckich ustaleniach powiadomił przebywającego w Londynie Sazonowa ambasador francuski Paul Cambon. Rosyjski minister, jakkolwiek przeciwny był jakiemukolwiek silniejszemu naciskowi na sojuszników bałkańskich, ostatecznie przystał na propozycję ${ }^{62}$. O fakcie tym Poincaré natychmiast poinformował rząd niemiecki i jednocześnie zaznaczył, że Niemcy powinny jak najszybciej powiadomić Austro-Węgry o podjętych ustaleniach ${ }^{63}$ i powstrzymać je przed podjęciem samodzielnej interwencji ${ }^{64}$.

${ }^{56}$ Материалы по истории...; s. 252, ÖUA, t. 4, nr 3720. Równocześnie dyplomacja rosyjska starała się wywierać naciski na państwa bałkańskie, wzywając je do zachowania spokoju, sugerując możliwość interwencji Austro-Węgier i Rumunii w przypadku konfliktu sojuszników z Turcją oraz deklarowała, że w takiej sytuacji nie udzieli im wsparcia, BD, t. 9, nr 674, 718, 732; ÖUA, t. 4, nr 3809.

57 R. Poincaré, op. cit., s. 73; Der diplomatische Schriftwechsel..., nr 402.

58 R. Poincaré, op. cit., s. 73-74.

59 Ibidem, s. 74-76.

${ }^{60}$ DGP, t. 33, nr 12191, 12209, 12210.

${ }^{61}$ Der diplomatische Schriftwechsel..., t. 2, nr 451, 483.

62 R. Poincaré, op. cit., s. 75; Der diplomatische Schriftwechsel..., t. 2, nr 456, 458.

${ }^{63}$ Polecenie takie Kinderlen przesłał telegraficznie niemieckiemu charge d'affairs w Wiedniu Friedrichowi zu Stolberg 30 września 1912 r., DGP, t. 33, nr 12190.

${ }^{64}$ Der diplomatische Schriftwechsel..., t. 2, nr 480. W Europie obawiano się bowiem, że wybuch wojny między sojusznikami i Turcja sprowokować może monarchię habsburską do zbrojnej interwencji, ibidem, s. 537-538. 
W dniu 3 października 1912 r. Sazonow przybył do Paryża. W rozmowach prowadzonych z premierem Francji potwierdził on gotowość podjęcia przez Rosję akcji mediacyjnej wspólnie z Austro-Węgrami, ale równocześnie podał w wątpliwość jej skuteczność, stwierdzając, że zaplanowane działania będą miały szanse powodzenia tylko wówczas, gdy mocarstwa zagwarantują jednocześnie przeprowadzenie reform w europejskiej części Turcji ${ }^{65}$. Wychodząc naprzeciw tym sugestiom, przygotowany przez Poincaré tekst memorandum, oprócz ustalonych wcześniej sformułowań, w których wzywano państwa bałkańskie do zachowania spokoju i status quo na Półwyspie oraz deklaracji, że mocarstwa nie wyrażą zgody na jakiekolwiek zmiany terytorialne bez względu na wynik ewentualnej konfrontacji zbrojnej, zawierał także gwarancje wielkich mocarstw dla reform w Macedonii i Tracji Adrianopolskiej ${ }^{66}$. Mimo pozornej zgody wszystkich zainteresowanych mocarstw, dyskusje nad redakcją dokumentu ${ }^{67}$ przeciągały się i ostatecznie przesłano go do państw bałkańskich dopiero 8 października 1912 r. ${ }^{68} \mathrm{~W}$ dwa dni później przekazana została również nota do Turcji, w której mocarstwa wzywały ją do przeprowadzenia reform w europejskich posiadłościach zgodnie z postanowieniami traktatu berlińskiego ${ }^{69}$. Posunięcia te były jednak mocno spóźnione. W tym czasie państwa bałkańskie były już bowiem gotowe do wojny. Kilka dni później sojusznicy bałkańscy przesłali do Konstantynopola własną notę dyplomatyczną, a po jej zignorowaniu przez Wysoką Portę, 18 października 1912 r., rozpoczęli działania wojenne.

Klęski Turcji w wojnie z blokiem bałkańskim, a zwłaszcza postępy wojsk bułgarskich, które w szybkim tempie zbliżały się do Konstantynopola, mocno zaniepokoiły wielkie mocarstwa ${ }^{70}$. Zajęcie tureckiej stolicy przez armię bułgarską stworzyłoby bowiem zupełnie nową sytuację polityczną w okolicach cieśnin czarnomorskich, tak ważnych z ekonomicznego i strategicznego punktu widzenia. Tymczasem utrzymująca się od wielu lat, niestabilna sytuacja polityczna w Bułgarii, wielokrotne zmiany gabinetów, przejmowanie władzy na przemian przez skrajnie różne

65 R. Poincaré, op. cit., s. 73; Der diplomatische Schriftwechsel..., t. 2, nr 472; DGP, t. 33, nr 12104.

${ }^{66}$ Tekst programu w: Der diplomatische Schriftwechsel..., t. 2, nr 48; T. von Sosnosky, op. cit., s. 278; M. Tanty, op. cit., s. 73; H. Batowski, Państwa bałkańskie 1800-1923. Zarys historii dyplomatycznej i rozwoju terytorialnego, Kraków 1938, s. 188.

676 października 1912 r. Austro-Węgry zażądały zmiany formy zapisu fragmentu dokumentu, R. Poincaré, op. cit., s. 76. Nowy projekt przedstawiony został 7 tego miesiąca (DGP, t. 33, nr 12240), ale gabinet wiedeński nie wierzył już w powodzenie akcji na Bałkanach, ibidem, t. 33 , nr 12166.

68 ÖUA, t. 4, nr 4009, 4010, 4018, 4019, 4020; H. Batowski, Państwa bałkańskie..., s. 188; T. von Sosnosky, op. cit., s. 279; W. Schröder, op. cit., s. 144-145.

69 ÖUA, t. 4, nr 4024, 4025, 4026. Tekst dokumentu w: И.Е. Гешов, Балканский Союз. Воспоминания и документы, Петроград 1915, s. 40; ÖUA, t. 4, aneks do nr 4102.

70 ÖUA, t. 4, nr 3879, 4165; B. von Siebert, op. cit., s. 565-567; Der diplomatische Schriftwechsel..., t. 2, nr 547, 566, 593; DGP, t. 33, nr 12364, t. 34, cz. 1, nr 12761; H. Batowski, Cieśniny Tureckie 1911-1936, Warszawa 1936, s. 8. 
programowo i reprezentujące zupełnie przeciwstawne zapatrywania na kierunki polityki zagranicznej partie, wytwarzała w stolicach europejskich przeświadczenie, że ani mocarstwa centralne, ani ententa nie będą w stanie zdobyć, a przede wszystkim ugruntować wpływów w rejonie Bosforu i Dardaneli. Stąd też oba przeciwstawne europejskie bloki militarno-polityczne podjęły wspólnie działania, mające na celu zabezpieczenie własnych interesów. Na przełomie października i listopada 1912 r. wielkie mocarstwa skierowały w okolice cieśnin czarnomorskich i na Morze Śródziemne eskadry swoich okrętów wojennych ${ }^{71}$. Jednocześnie obawy wywołane przebiegiem wydarzeń na Bałkanach postanowiła wykorzystać Turcja, która 3 listopada zezwoliła okrętom państw sygnatariuszy traktatu berlińskiego na wejście do Dardaneli ${ }^{72}$, licząc, że obecność ich flot z jednej strony powstrzyma Bułgarów przed podjęciem prób opanowania Konstantynopola, z drugiej uchroni stolicę przed skutkami ewentualnego buntu zdemoralizowanych jednostek zgromadzonych w jej okolicach. W związku z tym między 5 a 19 listopada do Konstantynopola przybyło łącznie 17 okrętów wojennych reprezentujących wielkie mocarstwa oraz Hiszpanię, Holandię i Rumunię ${ }^{73}$. Z ich załóg utworzony został liczący ponad 2500 marynarzy, w tym 576 Niemców i 161 Austriaków, międzynarodowy korpus pod dowództwem francuskiego kontradmirała Louis du Fourneta, który zajął strategiczne punkty w mieście. Korpus ten stanowić miał siły rozjemcze na wypadek wejścia armii bułgarskiej do Konstantynopola ${ }^{74}$. Równocześnie rozpoczęły się zabiegi dyplomatyczne, mające na celu zakończenie działań wojennych i normalizację stosunków politycznych na Półwyspie Bałkańskim ${ }^{75}$, do których asumpt dały działania Turcji. Porażony klęskami armii rząd turecki już 4 listopada zwrócił się do mocarstw z prośbą o pośrednictwo w kwestii zawarcia pokoju z państwami sojuszu bałkańskiego ${ }^{76}$. Ponieważ jednak zwlekały one z udzieleniem jednoznacznej odpowiedzi ${ }^{77}, 13$ tego miesiąca wielki wezyr Kâmil-pasza w imieniu Wysokiej Porty przesłał do Sofii depeszę ${ }^{78}$, k której, powołując się na interwencję u wielkich

${ }^{71} \mathrm{~W}$ akcji tej mocarstwa centralne reprezentowane były przez austro-węgierską eskadrę złożoną z: okrętów liniowych „Erzherzog Franz Ferdinand”, „Feldmarschall Graf von Radetzky” i „Zrinyi”, krążowników „Aspern” i „Admiral Spaun” i trzech kontrtorpedowców oraz niemiecki dywizjon składający się z czterech krążowników - „Vineta”, „Herta”, „Goeben” i „Breslau”.

72 ÖUA, t. 4, nr 4252.

73 J. Gozdawa-Gołębiewski, Od wojny krymskiej do bałkańskiej. Działania flot wojennych na morzach i oceanach w latach 1853-1914, Gdańsk 1985, s. 448, przyp. 1; na ten temat także: М. Семов, op. cit., s. 117-118.

${ }^{74}$ J. Gozdawa-Gołębiewski, op. cit., s. 118.

75 W. Schröder, op. cit., s. 158-209.

76 ÖUA, t. 4, nr 4251, 4265, 4268, 2496 n.; Der diplomatische Schriftwechsel..., t. 2, nr 546; М. Семов, op. cit., s. 106.

77 Brak odpowiedzi ze strony mocarstw wynikał z toczących się już od połowy października dyskusji na temat zakresu i warunków ewentualnej mediacji, m.in.: Der diplomatische Schriftwechsel..., t. 2, 531, 534, 549; DGP, t. 33, nr 12269, 12270, 12302, 12305, 12307, 12310; ÖUA, t. 4, nr 4167, 4200, 4216, 4221, 4241.

78 ÖUA, t. 4, nr 4421. 
mocarstw, zwracał się z propozycją zawarcia rozejmu i rozpoczęcia rozmów pokojowych oraz prosił cara Ferdynanda o poparcie tej idei u innych sojuszników.

Pertraktacje rozpoczęly się 25 listopada $1912 \mathrm{r} \cdot{ }^{79}$ Uczestniczyli w nich, oprócz Bułgarów i Turków, także delegaci serbscy, czarnogórscy i greccy. Po kilku dniach dyskusji, 3 grudnia w Czataldży podpisany został protokół ${ }^{80}$, który stwierdzał, że działania wojenne wstrzymane zostaną do momentu zakończenia rozmów pokojowych, rozpoczynających się w Londynie pod nadzorem wielkich mocarstw. Kuratela ta stanowić mogła dla sojuszników bałkańskich okoliczność sprzyjającą. Po wybuchu wojny na Półwyspie mocarstwa porzuciły bowiem lansowaną wcześniej ideę o nienaruszalności status quo na Bałkanach, podkreślając jednocześnie, że warunkiem ewentualnego podziału europejskich posiadłości Turcji jest natychmiastowe wstrzymanie operacji wojennych. Niepodlegającą żadnej dyskusji kwestią była także sprawa przynależności Konstantynopola, który bezwarunkowo pozostać miał w granicach Turcji. Wyrazem tego stanowiska były deklaracje, składane przez przedstawicieli wielkich mocarstw. Już 2 listopada 1912 r. minister spraw zagranicznych Rosji Sazonow poinformował rosyjskich posłów w stolicach europejskich, że Petersburg nie będzie sprzeciwiał się zmianom terytorialnym na Półwyspie, o ile te przeprowadzone zostaną bez jakiegokolwiek zaangażowania się innych mocarstw i dotyczyć będą wszystkich zainteresowanych państw bałkańskich. Podział ten oparty miał zostać na polubownym podziale zdobytych terytoriów, zgodnie z warunkami określonymi w zawartych przez sojuszników umowach ${ }^{81}$. Trzy dni wcześniej doszło do spotkania bułgarskiego posła w Londynie Nikołaja Madżarowa z brytyjskim ministrem finansów Davidem Lloydem George'em. W czasie rozmowy angielski polityk stwierdził, iż gabinet Edwarda Greya opowiada się za podziałem tureckich posiadłości w Europie. Równocześnie Lloyd George zagwarantował, że ideę taką popierają również Francja i Rosja ${ }^{82} .3$ listopada w tym samym duchu wypowiedział się austriacki minister spraw zagranicznych Berchtold. Na forum parlamentu stwierdził on, że w związku z aktualną sytuacją polityczną, Austro-Węgry dostrzegają konieczność dokonania poważnych korekt $\mathrm{w}$ dotychczasowym przebiegu linii granicznych państw bałkańskich ${ }^{83}$.

Ta niezwykła zgodność konkurujących o wpływy na Półwyspie mocarstw nie była jednak podyktowana chęcią wynagrodzenia sojusznikom ich wysiłków wojennych czy też potwierdzeniem słuszności narodowych ideałów, którymi kierowali się oni, przystępując do konfrontacji z Turcją. Zgłaszana przez wielkich graczy

79 ÖUA, t. 4, nr 4622. Na temat przebiegu pertraktacji: ibidem, t. 4, nr 4680, 4705, 4722, t. 5, nr 4747; H. Rohde, Meine Erlebnisse im Balkankrieg und kleine Skizzen aus dem türkischen Soldatenleben, Berlin 1913, s. 52-57, 60-61.

80 Tekst dokumentu w: J. Rubacha, A. Malinowski, A. Giza, Historia Bułgarii 1870-1915. Materiały źródłowe z komentarzami, t. 1: Polityka międzynarodowa, Warszawa 2004, s. 109-110; E.C. Helmreich, The diplomacy of the Balkan wars, 1912-1913, Cambridge 1938, s. 203.

${ }_{81}$ Материаль по истории..., s. 293; Der diplomatische Schriftwechsel..., t. 2, nr 544.

82 B. von Siebert, op. cit., s. 565-567.

83 ÖUA, t. 4, nr 4227. 
od końca października $1912 \mathrm{r}^{84}$ chęć mediacji między stronami konfliktu podyktowana była tylko i wyłącznie partykularnymi interesami. Z ich punktu widzenia sytuacja na Bałkanach poważnie się skomplikowała. Zdobycie przez Bułgarów Konstantynopola, opanowanie przez Greków lub Bułgarów Salonik, ulokowanie się Serbów na wybrzeżu albańskim, ale przede wszystkim osłabienie Turcji przeciągającą się wojną stanowić mogło poważne zagrożenie dla ich ekonomicznych i politycznych wpływów w tej części świata ${ }^{85}$. Wymownym potwierdzeniem takiego stanowiska była akcja morska w Konstantynopolu, poprzez którą dały one sojusznikom bałkańskim, a zwłaszcza Bułgarii, wyraźnie do zrozumienia, że w razie konieczności podejmą najdalej idące kroki na rzecz ratowania Turcji przed ostateczną klęską ${ }^{86}$. Oprócz kwestii przyszłości Konstantynopola, która w związku $\mathrm{z}$ niejednolitymi wypowiedziami bułgarskich politykó $\mathrm{w}^{87}$ budziła w Europie poważnie niepokoje, niezwykle pilna do rozwiązania była sprawa serbskich aspiracji do wybrzeża albańskiego.

Możliwość uzyskania dostępu do morza w drodze aneksji północnych terenów Albanii serbscy politycy rozważali już na przełomie XIX i XX w., ale dopiero w okresie I wojny bałkańskiej idea ta mogła zostać wprowadzona w życie. Plany Belgradu stały jednak w poważnej sprzeczności z interesami mocarstw, a w szczególności najbardziej zainteresowanych tą częścią Półwyspu Bałkańskiego - Austro-Węgier i Włoch ${ }^{88}$, które mocno postulowały utworzenie autonomicznej prowincji albańskiej lub niepodległego państwa albańskiego. Równocześnie w Europie obawiano się, że aspiracje serbskie mogą zostać poparte przez pozostałych sojuszników bałkańskich, co groziło poważnymi konsekwencjami w przypadku ewentualnej konfrontacji. Stąd też politycy wielkich mocarstw rozpoczęli pospieszne sondowanie stanowiska w tej sprawie najważniejszego spośród nich - Bułgarii. Ponieważ kwestia albańska nie leżała w kręgu głównych zainteresowań bułgarskich, stanowisko Sofii - ogólnie - zgodne było z koncepcjami mocarstw. Już podczas spotkania Madżarowa z Lloydem George’em bułgarski poseł zajął stanowisko, że Albania powinna otrzymać autonomię. Z naciskiem jednak podkreślił, że prawa ludności chrześcijańskiej muszą zostać wyraźnie zagwarantowane, a najlepiej byłoby, gdyby kontrola nad ich przestrzeganiem powierzona została państwom bałkańskim. Jednocześnie jednak

${ }^{84}$ W. Schröder, op. cit., s. 159-160; M. Семов, op. cit., s. 104-105.

85 B. von Siebert, op. cit., s. 553-554.

${ }^{86}$ Ibidem, s. 553.

87 W toku rozmowy z Lloydem Geroge'em 31 listopada 1912 r. Madżarow powiedział: „Konstantynopol i Dardanele nie interesują nas, ale jako kwestię najwyższej wagi stawiamy dostęp do wybrzeża Morza Egejskiego", М. Семов, op. cit., s. 103. Kilka dni później poseł bułgarski w Wiedniu Iwan Sałabaszew podczas spotkania z Berchtoldem stwierdził natomiast: „Turcja musi ostatecznie opuścić Europę. Jej europejskie prowincje należy rozdzielić między chrześcijańskie państwa bałkańskie. Konstantynopol powinna otrzymać Bułgaria”, ibidem, s. 106.

${ }^{88} \mathrm{Na}$ temat stosunku Włoch i Austro-Węgier do serbskich planów uzyskania dostępu do Morza Adriatyckiego wiele dokumentów w B. von Siebert, op. cit., s. 571-592; na ten temat także: ÖUA, t. 4, nr 4170, 4206, 4359, 4373 n.; DGP, t. 33, nr 12320. 
przebywający z wizytą w Budapeszcie w połowie listopada 1912 r. Sojan Danew $\mathrm{w}$ rozmowie $\mathrm{z}$ Berchtoldem starał się utwierdzić austriackiego ministra $\mathrm{w}$ przeświadczeniu, że Bułgaria popiera starania Serbii o dostęp do Adriatyku ${ }^{89}$, ale, jak słusznie zauważa Minczo Semow, był to raczej rodzaj gry politycznej niż rzeczywiste stanowisko rządu bułgarskiego ${ }^{90}$. W tym czasie mocarstwa zaczęły bowiem wysuwać koncepcję, która z związku ze stanowczym sprzeciwem trójprzymierza w kwestii serbskich nabytków terytorialnych kosztem Albanii przewidywała możliwość udostępnienia Serbom dostępu do Morza Egejskiego ${ }^{91}$. Idea ta spotkała się $\mathrm{z}$ dużym niezadowoleniem w Bułgarii ${ }^{92}$. W związku z tym, im mocarstwa większy nacisk kładły na serbski dostęp do morza na południu, tym silniej Bułgaria popierała dążenia Serbów do opanowania północnej Albanii. Dopiero stanowcze oświadczenie Austro-Węgier i Włoch ${ }^{93}$, że związane porozumieniem w tej kwestii od 1891 r. nie dopuszczą do zmian terytorialnych w zachodniej części Półwyspu Bałkańskiego, spowodowało wycofanie się Bułgarii z poparcia dla Belgradu. Poza tym kwestia albańska nabrała zupełnie innego wymiaru. 28 listopada 1912 r. zgromadzeni we Wlorze notable albańscy pod przewodnictwem Izmaila Kemala-beja

89 M. Семов, op. cit., s. 109. Stanowisko takie Danew zaprezentował już podczas rozmowy z posłem austro-węgierskim w Sofii Adamem Tarnowskim 7 listopada 1912 r., ÖUA, t. 4, nr 4314, 4407. Podobne stanowisko zajął również Iwan E. Geszow, ibidem, t. 4, 4407, 4408, oraz bułgarski poseł w Petersburgu Paprikow, Der diplomatische Schriftwechsel..., t. 2, nr 565. Serbskie pretensje do wybrzeży albańskich popierali także Grecy, ÖUA, t. 4, nr 4431, 4432, 4490.

90 M. Семов, op. cit., s. 109; ÖUA, t. 5, nr 4929.

91 ÖUA, t. 4, nr 4326, 4379; B. von Siebert, op. cit., s. 573; M. Семов, op. cit., s. 108. Równocześnie Austro-Węgry, korzystające z poparcia Niemiec (na ten temat: E.C. Helmreich, op. cit., s. 236 n.) groziły Serbii interwencją zbrojną, jeżeli ta nie zrezygnuje z wybrzeży albańskich. Tymczasem politycy serbscy zdecydowanie odrzucali taką możliwość, DGP, t. 33, nr 12363; ÖUA, t. 4, nr 4351, 4353, 4354, 4365, 4371 n., t. 5, nr 4741, 4792 n. Sytuacja stała się na tyle napięta, że udzielająca Serbom silnego poparcia Rosja (ibidem, t. 4, nr 4394; B. von Siebert, op. cit., s. 577-578), na skutek postawy Anglii i Francji, które zgodnie oświadczyły, że „nie zamierzają prowadzić wojny z mocarstwami centralnymi z powodu serbskiego portu nad Adriatykiem” (B. von Siebert, op. cit., s. 578; ÖUA, t. 5, nr 4853, 4854; W. Schröder, op. cit., s. 175), ostatecznie wycofała się z niego, wzywając Serbów do podporządkowania się woli mocarstw (B. von Siebert, op. cit., s. 579; ÖUA, t. 4, nr 4458). Równocześnie Edward Grey wystąpił z propozycją rozwiązania sporu poprzez budowę eksterytorialnej linii kolejowej, łączącej granicę serbską z którymś z portów adriatyckich, która, znajdując się pod pełną kontrolą serbską, zabezpieczałaby ekonomiczne interesy Belgradu (B. von Siebert, op. cit., s. 580; ÖUA, t. 4, nr 4170, 4382). Koncepcja ta ostatecznie przyjęta została przez Austro-Węgry (B. von Siebert, op. cit., s. 595; DGP, t. 34, cz. 1, nr 12579), ale nie zyskała aprobaty strony serbskiej.

92 Г. Марков, България в Балканския съюз срещу Османската империя 1912-1913, София 1989, s. 111; И.Е. Гешов, Лична кореспонденция, София 1994, s. 245-247.

93 Już 30 października 1912 r. Berchtold oświadczył, że Austro-Węgry nie dopuszczą do usadowienia się Serbów nad Adriatykiem i popierać będą ideę stworzenia niepodległego państwa albańskiego, a 8 listopada oficjalnie powiadomił o tym rząd serbski. Takie samo stanowisko przyjęły także Włochy oświadczając 4 listopada, że: „korytarz serbski do Adriatyku nie da się pogodzić z interesami Włoch”, H. Batowski, Państwa bałkańskie..., s. 197. Na ten temat także: Материаль no uстории..., s. 294; M. Tanty, op. cit., s. 104-106 n. 
ogłosili niepodległość Albanii ${ }^{94}$. Równocześnie nowy rząd tymczasowy zaprotestował przeciw obecności wojsk sojuszu bałkańskiego na ziemiach albańskich i zwrócił się do Austro-Węgier i Włoch z prośbą o opiekę. Protekcja mocarstw nad Albanią sprawiła, że niezamierzająca wchodzić w konflikt z monarchią habsburską Bułgaria nie podejmowała więcej tej kwestii.

W takiej atmosferze 17 grudnia 1912 r. rozpoczęła się konferencja pokojowa w Londynie. W obradach udział wzięły delegacje Bułgarii, Serbii, Grecji, Czarnogóry i Turcji oraz konferencja ambasadorów wielkich mocarstw, która działała niezależnie, rozpatrując kwestie związane $z$ ich interesami i sprawując jedynie ogólny nadzór nad przebiegiem obrad sojuszników bałkańskich z Wysoką Portą. Negocjacje $\mathrm{w}$ trakcie konferencji pokojowej nie przebiegały gładko, co wynikało przede wszystkim z postawy Turcji, niezamierzającej, mimo klęski poniesionej w wojnie, rezygnować ze swoich europejskich posiadłości. Taki stan rzeczy wielokrotnie zmuszał wielkie mocarstwa do ingerowania w przebieg obrad, ale mimo ich nacisków strony nie mogły dojść do porozumienia. Ostatecznie doprowadziło to do zerwania rozmów i wznowienia działań wojennych, w trakcie których Turcy ponieśli kolejne klęski, tracąc oblężone do tej pory twierdze w Adrianopolu i Janinie.

$\mathrm{Z}$ punktu widzenia mocarstw centralnych zdecydowanie większe znaczenie miały jednak obrady konferencji ambasadorów, w trakcie których omawiana była m.in. kwestia albańska. W toku dyskusji poważne kontrowersje budziła sprawa przebiegu granic przyszłego państwa, co ostatecznie doprowadziło do wykrystalizowania się trzech koncepcji. Pierwszą reprezentowali sami Albańczycy, którzy postulowali objęcie granicami ich państwa wszystkich czterech wilajetów, na terenie których ogłoszona została przez Turków w 1912 r. autonomia. Jednak żądań tych nie były w stanie przeforsować nawet niezwykle przychylnie nastawione do Albańczyków Włochy i Austro-Węgry. Stąd też te ostatnie proponowały, aby granica nowego państwa bałkańskiego przebiegała wzdłuż dotychczasowej granicy czarnogórsko-tureckiej, obejmując Szkodrę na północy, następnie biegnąc na południe, pozostawiając po stronie albańskiej m.in. Prizren, Debar i Ochrydę, oraz objęła znaczną część Epiru z Janiną na południu. W opozycji do obu tych koncepcji stała propozycja wysunięta przez sojuszników bałkańskich i popierana przez Rosję. Przewidywała ona, że granice przyszłej Albanii przebiegać będą od ujścia rzeki Mati, następnie na zachód od Czarnego Drinu i, pozostawiając Grecji miejscowości Konitsa i Gjirokastra, dotrą do Morza Adriatyckiego w okolicach Zatoki Wlorskiej ${ }^{95}$. Spory w tej kwestii były tak zacięte, że omal nie doprowadziły do wybuchu konfliktu między Rosją i Austro-Węgrami ${ }^{96}$. Ostatecznie jednak konferencja ambasadorów 22 marca $1913 \mathrm{r}$. przyjęła projekt wysunięty przez Austro-Węgry, który tworzył państwo albańskie na obszarze dwóch dawnych

\footnotetext{
${ }_{94}$ Der diplomatische Schriftwechsel..., t. 2, nr 595; ÖUA, t. 4, nr 4716.

${ }_{95} \mathrm{Na}$ ten temat wiele dokumentów w DGP, t. 34, cz. 1.

96 M. Tanty, op. cit., s. 128-131.
} 
wilajetów tureckich: szkoderskiego i janińskiego, a cztery miesiące później mocarstwa uchwaliły statut Albanii i uznały ją za niepodległe księstwo pod protektoratem wielkich mocarstw ${ }^{97}$. Równocześnie, w związku z protestami Czarnogóry i Serbii, podjęto zdecydowane kroki na rzecz złamania ich oporu, grożąc blokadą morską wybrzeża czarnogórskiego, a Włochy i Austro-Węgry 8 maja tego roku zawarły tajne porozumienie, w którym zobowiązywały się, w razie konieczności, do wspólnej okupacji terytorium albańskiego, która zabezpieczyć je miała przed ewentualną obcą interwencją ${ }^{98}$. To stanowisko mocarstw zmusiło do ustępstw zarówno Czarnogórców, jak i Serbów, którzy 12 kwietnia 1913 r. wycofali swój korpus spod Szkodry, a następnie opuścili zajęte terytorium albańskie ${ }^{99}$.

Z punktu widzenia Austro-Węgier, a także w pewnym sensie Niemiec, zdecydowanie mniejsze znaczenie miały rozstrzygnięcia przyjęte przez drugą turę konferencji londyńskiej, która zakończyła się 30 maja 1913 r. podpisaniem pokoju pomiędzy sojusznikami bałkańskimi a Turcją. Na jego mocy Wysoka Porta traciła na rzecz Bułgarii, Serbii, Czarnogóry i Grecji wszystkie swoje europejskie posiadłości do linii Enez - Midye. Taki stan rzeczy niewątpliwie nie był zgodny zwłaszcza z niemiecką racją stanu, ponieważ narażał na szwank niemieckie interesy w Turcji oraz pod znakiem zapytania stawiał możliwość właściwego wykorzystania zainwestowanych tam w okresie wcześniejszym kapitałów, ale przed mocarstwami centralnymi otwierało się nowe pole do działania.

Zawarte wiosną i latem 1912 r. przez państwa bałkańskie porozumienia, które w historiografii określane są mianem „sojuszu bałkańskiego”, w rzeczywistości nie tworzyły jednolitego bloku, a były jedynie zbiorem dwustronnych porozumień. Warto także podkreślić, że postanowienia poszczególnych dokumentów były często nieprecyzyjne, a nawet wzajemnie się wykluczały. Taki stan rzeczy sprawiał, że mogły być one różnie interpretowane, co w miarę upływu czasu prowadziło do nieporozumień i napięć w łonie sojuszu. Szczególnego wymiaru nabrały spory toczące się między Bułgarią i Serbią, w których rozjemcą, zgodnie z zapisami traktatu łączącego oba państwa, miała być Rosja. Jakkolwiek dyplomacji rosyjskiej bardzo zależało na utrzymaniu spoistości bloku bałkańskiego, w miarę upływu czasu coraz wyraźniej popierała roszczenia serbskie i wywierała coraz silniejsze naciski na Bułgarię, aby ta również je zaakceptowała. Spełnienie tych roszczeń nie było jednak możliwe, ponieważ musiałoby się wiązać z porzuceniem przez Bułgarów narodowych celów, jakie sobie stawiali, przystępując do wojny z Turcją. Stąd też w Sofii narastała niechęć do Rosji, a do głosu zaczęły dochodzić środowiska opozycyjne, jawnie wzywające do zbliżenia z mocarstwami centralnymi. Taki stan rzeczy stwarzał tym ostatnim szansę na wyrwanie Bułgarii z kręgu wpływów rosyjskich

\footnotetext{
97 H. Batowski, Państwa bałkańskie..., s. 198-202; E.C. Helmreich, op. cit., s. 296; na ten temat wiele dokumentów w: DGP, t. 34, cz. 2.

98 Dokumente aus russischen Geheimarchiven soweit sie bis zum 1. Juli 1918 eingegangen sind, hrsg. vom Ausvärtgen Amt, Berlin 1919, s. 38-41.

99 Материальь по истории..., s. 363.
} 
i uczynienie z niej ważnego elementu własnego bloku militarno-politycznego, dającego wgląd nie tylko w to, co dzieje się na Półwyspie Bałkańskim, ale przede wszystkim ugruntowującego ich pozycję w okolicach cieśnin czarnomorskich. Jakkolwiek ani Austro-Węgry, ani Niemcy nie miały możliwości wywarcia nacisku na Serbię, szansę pozyskania Bułgarii stwarzało podjęcie się mediacji w nowym sporze na Bałkanach - sporze bułgarsko-rumuńskim o południową Dobrudżę.

Stosunki na linii Bukareszt - Sofia ulegały stopniowemu pogorszeniu od momentu wybuchu wojny z Turcją. Rumuni zadeklarowali bowiem, że w przypadku zmian na politycznej mapie Bałkanów domagać się będą rekompensat terytorialnych za rzekome naruszenie równowagi w regionie. Równocześnie jednak, w związku faktem, że Rumunia nie posiadała wspólnej granicy z Turcją, roszczenia te wysunięte zostały w stosunku do Bułgarii i dotyczyły przekazania południowej Dobrudży. Jakkolwiek rząd bułgarski lekceważył początkowo zagrożenie ze strony północnego sąsiada, starał się uregulować wzajemne stosunki. Podjęte jednak już pod koniec 1912 r. działania nie zakończyły się sukcesem, a wzrost napięcia między Bułgarią a innymi członkami bloku bałkańskiego uświadomił władzom bułgarskim, że nie mogą pozwolić sobie na prowokowanie konfliktu z Rumunią ${ }^{100}$. Stąd też jeszcze w styczniu 1913 r. w Londynie Stojan Danew podjął konsultacje $\mathrm{z}$ delegatami rumuńskimi ${ }^{101}$ na temat opracowanego w Bukareszcie projektu, który przewidywał przekazanie Rumunom pasa terytorium bułgarskiego między położonym nad Dunajem Tutrakanem, a Bałczikiem w południowej Dobrudży, o łącznej powierzchni ok. $3000 \mathrm{~km}^{2}$ oraz zagwarantowanie pełnych praw i autonomii kościelno-kulturalnej Kucowołochom w Macedonii ${ }^{102}$. O ile jednak strona bułgarska bez problemów gotowa była zapewnić realizację drugiego z postulatów, o tyle nie dopuszczała możliwości oddania tak znacznej części terytorium ${ }^{103}$. Twardego stanowiska Bułgarii nie były w stanie złamać nawet wyrażane przez prowadzącego rozmowy w imieniu gabinetu rumuńskiego Nicolae Mişu groźby, że w przypadku braku konstruktywnej odpowiedzi Bułgarii Rumunia nie cofnie się przed podjęciem kroków zbrojnych ${ }^{104}$ i zajmie sporne terytorium siłą. W związku z tym rozmowy utknęły w martwym punkcie ${ }^{105}$, a za taki stan rzeczy Rumuni

100 А. Тошев, Балканските войни, t. 2, София 1931, s. 132.

101 Delegacja rumuńska wzięła udział obradach konferencji pokojowej w Londynie, mimo że Rumunia nie była stroną w konflikcie między sojusznikami bałkańskimi a Turcją. Przybyła ona na obrady na specjalne zaproszenie mocarstw i otrzymała prawo uczestnictwa w dyskusjach nad kwestiami, które będą Rumunię szczególnie interesować, DGP, t. 34, cz. 1, nr 12564. Równocześnie jednak zaznaczyć należy, że Rumunia już z końcem października $1912 \mathrm{r}$. bardzo wyraźnie akcentowała, że swój udział w konferencji pokojowej uważa za konieczny, ÖUA, t. 4, nr 4173, 4211. Stanowisko to poparły ostatecznie Niemcy i Austro-Węgry, ibidem, t. 4, nr 4211, 4212.

102 ÖUA, t. 5, nr 5257, 5262; Г. Марков, ор. cit., s. 184-185; И.Е. Гешов, Лична..., s. 250-252 i 253-254.

103 ÖUA, t. 5, nr 5262, 5428, 5557.

104 ÖUA, t. 5, nr 5334, 5334, 5437, 5451, 5565, 5590 n.; DGP, t. 34, cz. 1, nr 12782.

105 ÖUA, t. 5, nr 5310, 5311, 5452, 5474 n. 
natychmiast oskarżyli stronę bułgarską ${ }^{106}$. Ostatecznie więc 29 stycznia $1913 \mathrm{r}$. w Londynie strony zdecydowały się jedynie na podpisanie protokołu, który stać się miał podstawą ewentualnych dalszych dyskusji ${ }^{107}$. Nie przyniosły także rezultatu rozmowy kontynuowane w Sofii na początku lutego ${ }^{108}$, a poważne rozbieżności między wysuwanymi przez Rumunię roszczeniami, a deklarowanymi przez Bułgarię ustępstwami z góry wskazywały, że do porozumienia nie dojdzie.

Fiasko rozmów bułgarsko-rumuńskich w Londynie wywołało duże zaniepokojenie w Europie ${ }^{109}$. W obliczu kontynuowanej przez sojuszników wojny z Turcją, kolejny konflikt na Półwyspie był jak najmniej pożądany. Równocześnie jednak spór między Rumunią i Bułgarią miał dla wielkich mocarstw bardzo istotne znaczenie, ponieważ państwa te odgrywały ważną rolę w planach obu przeciwstawnych bloków politycznych. Stąd też podejmowane przez nie, a zwłaszcza najbardziej zainteresowane Austro-Węgry i Rosję, próby mediacji ${ }^{110}$ nacechowane były dużą ostrożnością, tak aby, jak słusznie stwierdził Henryk Batowski, „utrzymać, względnie pozyskać, pierwszą i nie stracić drugiej"111. Działania te nie przynosiły jednak spodziewanych rezultatów, dlatego też ostatecznie oba mocarstwa aktywnie poparły wysuniętą w połowie lutego 1913 r. przez delegata Włoch, Antonia di San Giuliano, ideę poddania tej kwestii mediacji wszystkich mocarstw europejskich ${ }^{112}$. Propozycja ta została przyjęta w Sofii bardzo nieufnie, a rząd bułgarski początkowo zwlekał $\mathrm{z}$ udzieleniem odpowiedzi ${ }^{113}$, ale ostatecznie 24 lutego zgodził się na $\operatorname{arbitraz} \dot{z}^{114}$. Konferencja rozpoczęła prace 31 marca w Petersburgu ${ }^{115}$, ale rozmowy toczyły się w bardzo napiętej atmosferze. Stąd też, mimo trwających ponad miesiąc dyskusji, nie udało się osiągnąć porozumienia i 9 maja strony zdecydowały się jedynie na podpisanie protokołu końcowego ${ }^{116}$. Bułgaria zobowiązywała

106 ÖUA, t. 5, nr 5050, 5310, 5311.

107 ÖUA, t. 5, nr 5589, 5592, 5621, 5671.

108 ÖUA, t. 5, nr 5669, 5713, 5718 n.; DGP, t. 34, cz. 1, nr 12778; M. Tanty, op. cit., s. 162.

109 DGP, t. 34, cz. 1, nr 12870, 12871.

110 DGP, t. 34, nr 12874, 12906, 12912, 12927; ÖUA, t. 5, nr 5308, 5309, 5310, 5311, 5326, 5349, 5616 n.; Der diplomatische Schriftwechsel..., t. 3, nr 707.

111 H. Batowski, Państwa bałkańskie..., s. 205. Potwierdzeniem takiego stanowiska mogą być wysuwane przez Austro-Węgry koncepcje, które przewidywały nakłonienie Bułgarii do ustępstw terytorialnych na rzecz Rumunii w zamian za poparcie jej roszczeń do Salonik lub kompensację strat na południu poprzez nabytki kosztem Serbii (DGP, t. 34, cz. 2, nr 13042; ÖUA, t. 5, nr 5585, $5586,5895,5618,6023,6025,6034,6076$ n.) oraz zapewnienia rządu rosyjskiego, że w konflikcie bułgarsko-rumuńskim Rosja popiera stanowisko Sofii (ÖUA, t. 5, nr 6026). Na temat stosunku Rosji do sporu bułgarsko-rumuńskiego M. Tanty, op. cit., s. 167-170 n.; o wysiłkach Austro-Węgier E.C. Helmreich, op. cit., s. 374.

112 ÖUA, t. 5, nr 5799, 5832.

113 ÖUA, t. 5, nr 5916, 5921.

114 ÖUA, t. 5, nr 5932.

115 ÖUA, t. 5, nr 6396; А. Кузманова, Румбнските териториални претенции за Южна Добруджа и Букурещкият договор, w: Букурещкия договор и съдбата на Южна Добруджа. Сборник с изследвания, Добрич 1994, s. 15.

116 Tekst dokumentu w: J. Rubacha, A. Malinowski, A. Giza, op. cit., s. 118-119. 
się do oddania Rumunii twierdzy Silistra wraz z trzykilometrowym pasem wokół niej i zburzenia pozostających na jej terytorium umocnień oraz gwarantowała pełne prawa Kucowołochom w Macedonii, a Rumunia - do wypłaty odszkodowań wszystkim mieszkańcom opuszczającym pozyskane terytorium. Wymuszona przez mocarstwa ugoda nie zadowoliła jednak żadnej ze stron, co stwarzało zagrożenie, że dążyć one będą do zmiany jej postanowień. W tej kwestii na uprzywilejowanej pozycji znalazła się Rumunia, która w dobie II wojny bałkańskiej podjęła udaną próbę zaspokojenia swych roszczeń. Tym samym działania Austro-Węgier na rzecz wzmocnienia swych wpływów w Bułgarii, mimo wsparcia niemieckiego, nie zakończyły się sukcesem. Nie oznaczało to jednak, że mocarstwa centralne nie podejmowały podobnych prób w okresie późniejszym.

Korzystając ze zmiany rządu w Bułgarii i dojścia do władzy ugrupowań o prozachodnim nastawieniu, wysiłki te podjęto w czasie trwania kongresu bukareszteńskiego, latem $1913 \mathrm{r}$. Jednak wsparcie mocarstw centralnych tylko nieznacznie wzmocniło pozycję Bułgarii, co nie pozwoliło osiągnąć sukcesów ani w kwestii podziału Macedonii, ani przynależności egejskiego portu Kavala. Poza tym Bułgarzy musieli pogodzić się z utratą południowej Dobrudży. Warto jednak podkreślić, że mimo to wpływy mocarstw centralnych w Bułgarii uległy wzmocnieniu, co pośrednio przesądziło o przystąpieniu tego kraju do I wojny światowej po ich stronie.

Podsumowując działania dyplomatyczne Austro-Węgier i Niemiec na Bałkanach w okresie poprzedzającym I wojnę bałkańską i w czasie jej trwania, należy stwierdzić, że były one kontynuacją wcześniej prowadzonej polityki. Polegała ona przede wszystkim na sukcesywnym poszerzaniu strefy wpływów w tej newralgicznej części Europy, przy równoczesnym rugowaniu obecności innych mocarstw, a zwłaszcza Rosji. Efekty podjętych działań, na które nie szczędzono sił i środków, nie przyniosły jednak spektakularnych sukcesów. Wprawdzie udało im się wyrwać Bułgarię spod kurateli rosyjskiej i zablokować serbskie plany opanowania wybrzeży adriatyckich, ale osłabienie Turcji i Bułgarii, które było wynikiem wojen bałkańskich, w znaczący sposób obniżało pozycję tych ostatnich jako partnerów politycznych, ekonomicznych i militarnych. Warto także podkreślić, że stworzona dzięki wysiłkowi dyplomatycznemu Austro-Węgier niepodległa Albania bardzo szybko znalazła się w orbicie wpływów włoskich.

\section{The Central Powers and the Balkans. A study of diplomatic activity of Germany and Austro-Hungary in South-Eastern Europe (1909-1913)}

\section{Abstract}

Due to its geographical location nestled between the "Western World" and the "World of the Orient", the Balkan Peninsula has for centuries been playing an important part both in European politics, and economy. Its significance increased sharply in the mid-nineteenth century, after the European powers entered the so-called imperial era. It is therefore not surprising 
that at that time this relatively small region at "the end of the civilised world" became the battlefield for zones of influence. The rivalry was also joined by Germany and Austro-Hungary. And although these states had different ultimate ends, it was known both in Berlin, and in Vienna that the advantage over the competitors and opponents could have a great impact not only on the development of national industry, which would gain a new ready market, but also on the shape of European policy. However, the processes of deep changes and transformations that occurred in the Balkans in the early twentieth century, wrongly identified and underestimated by the diplomacy of Central Powers, determined their abject failure in the attempts to strengthen their position in South-Eastern Europe. Thus, in a conflict at the turn of 1913 between the Balkan states and Turkey that diplomacy played a secondary role and achieved little success. And although diplomats of the Central Powers were able to free Bulgaria from the grip of Russian control and block Serbian plans to seize the Adriatic Coast, but the weakening of Turkey and Bulgaria after the Balkan Wars decreased significantly their role as political, economic and military partners. It is also worth emphasising that independent Albania, formed thanks to diplomatic efforts of Austro-Hungary, went quickly into the Italian sphere of influence.

Translated by Grażyna Waluga

\section{Центральные державы и Балканы. Исследование дипломатических действий Германии и Австро-Венгрии в Юго-восточной Европе (1909-1913)}

\section{Абстракт}

Балканский полуостров из-за своего географического положения на стыке «западного» и «ориентального» миров на протяжении многих столетий играл важную роль, как в европейской политике, так и экономике, а его значение существенно увеличилось в середине XIX в., когда европейские державы вступили в т. н. имперскую эру. Итак, не удивительно, что именно в это время этот небольшой регион, находящийся на «краю цивилизованной Европы», стал полем упорной борьбы за сферы влияния. В этом соперничестве приняли участие также Германия и Австро-Венгрия. Хотя эти государства по-другому воспринимали конечные цели, как в Берлине, так и в Вене отдавали себе отчет в том, что опережение соперников может существенно повлиять не только на развитие отечественного промышленности, которая приобрела бы новые рынки сбыта для своей продукции, но и на формирование общеевропейской политики. Однако процессы и глубокие перемены, происходящие на Балканах в начале XX в., подверглись ошибочной оценке и были недооценены дипломатическими службами центральных держав. Оттуда и в конфликте, происходящем на рубеже 1912 и 1913 гг, между балканскими государствами и Турцией, они сыграли второстепенную роль и не были в состоянии добиться более существенных успехов. Хотя дипломатам центральных держав удалось вырвать Болгарию из-под российской опеки и заблокировать сербские планы захвата адриатического берега, но ослабление Турции и Болгарии вследствие балканских войн в значительной мере ослабило и их положение, как политических, экономических и военных партнеров. Стоит также подчеркнуть, что независимая Албания, созданная благодаря дипломатическим усилиям Австро-Венгрии, очень быстро попала в орбиту итальянских влияний. 


\section{Bibliografia}

\section{Źródła:}

British Documents on the Origins of the War 1898-1914, London 1926.

Der diplomatische Schriftwechsel Iswolskis 1911-1914, hrsg. F. Stieve, Berlin 1926.

Die große Politik der europäischen Kabinette, 1871-191. Sammlung der diplomatischen Akten des Auswärtigen Amtes, hrsg. J. Lepsius, A. Mendelssohn-Bartholdy, F. Thimme, Berlin 1922-1926.

Dokumente aus russischen Geheimarchiven soweit sie bis zum 1. Juli 1918 eingegangen sind, hrsg. vom Ausvärtgen Amt, Berlin 1919.

Österreich-Ungarns Aussenpolitik von bosnischen Krise 1908 bis zum Kriegsausbruch 1914. Diplomatische Aktenstücke des Österreich-Ungarischen Aussenministeriums, ausgew. L. von Bittner, A.F. Pribram, H. Srbik, H. Übersberger, Wien/Leipzig 1930.

Poincaré R., Geneza wojny światowej. Sześć odczytów wygłoszonych w Paryżu w roku 1921, Kraków 1921.

Rohde H., Meine Erlebnisse im Balkankrieg und kleine Skizzen aus dem türkischen Soldatenleben, Berlin 1913.

Rubacha J., Malinowski A., Giza A., Historia Bułgarii 1870-1915. Materiały źródłowe z komentarzami, t. 1: Polityka międzynarodowa, Warszawa 2004.

Siebert B. von, Diplomatische Aktenstücke zur Geschichte der Ententepolitik der Vorkriegsjahre, Berlin 1921.

Гешов И.Е., Балканский Союз. Воспоминания и документы, Петроград 1915.

Гешов И.Е., Лична кореспондениия, София 1994.

Материаль по истории франко-русских отношений за 1910-1914 г2. Сборник секретных дипломатических документов Быьш. Императорского Министерства Иностранных Дел, отв. ред. Р. Маршан, Москва 1922.

Тошев А., Балканските войни, t. 2, София 1931.

\section{Opracowania:}

Batowski H., Cieśniny Tureckie 1911-1936, Warszawa 1936.

Batowski H., Państwa bałkańskie 1800-1923. Zarys historii dyplomatycznej i rozwoju terytorialnego, Kraków 1938.

Bickel O., Russland und die Entstehung des Balkanbundes 1912. Ein Beitrag zur Vorgrschichte des Weltkrieges. Dargestellt vorwiegend auf Grund des amtlichen Aktenmaterials, Königsberg/Berlin 1933.

Bogdan H., From Warsaw to Sofia. A History of Eastern Europe, Santa Fe 1989.

Czubiński A., Państwa bałkańskie w polityce imperializmu niemieckiego w latach 1871-1945. w: Referaty i komunikaty wygłoszone $w$ czasie sympozjum zorganizowanego przez Zakład Historii Powszechnej, Nowożytnej i Najnowszej Instytutu Historii UAM w Poznaniu $w$ dniach 24-25 listopada 1980 r., red. A. Czubiński, Poznań 1982.

Gozdawa-Gołębiewski J., Od wojny krymskiej do bałkańskiej. Działania flot wojennych na morzach i oceanach w latach 1853-1914, Gdańsk 1985.

Helmreich E.C., The diplomacy of the Balkan wars, 1912-1913, Cambridge 1938.

Roloff G., Die Entstehung des Balkanbundes von 1912, Geissen 1922.

Schröder W., England, Europa und der Orient, Stuttgart 1938.

Sosnosky T. von, Die Balkanpolitik Österreich-Ungarns seit 1866, Stuttgart/Berlin 1914. 
Steed H.W., The Hapsburg Monarchy, London 1919.

Stefański Z., Wojna dyplomatów, „Świat Słowiański” 5, 1909, t. 1, nr 53, s. 332.

Tanty M., Rosja wobec wojen bałkańskich 1912-1913, Warszawa 1970.

Кузманова А., Румънските териториални претенции за Южна Добруджа и Букурещкият договор, w: Букурещкия договор и съдбата на Южна Добруджа. Сборник с изследвания, Добрич 1994.

Марков Г., България в Балканския съюз срещу Османската империя 1912-1913, София 1989.

Семов М., Победителят проси мир. Балканските войни 1912-13, София 1995.

Jarosław Rubacha, dr hab., historyk, bałkanista, profesor Uniwersytetu Warmińsko-Mazurskiego w Olsztynie; zajmuje się historią Półwyspu Bałkańskiego w XIX i XX w., historią Bułgarii i polskim słowianofilstwem na początku XX stulecia (j.rubacha@wp.pl).

Jarosław Rubacha, Dr. hab., historian of the Balkans, professor of the University of Warmia and Mazury in Olsztyn; his research interests focus on the history of the Balkan Peninsula in the $19^{\text {th }}$ and $20^{\text {th }}$ century, history of Bulgaria and Polish Slavophilia in the early $20^{\text {th }}$ century (j.rubacha@wp.pl). 